\title{
Estudio de morteros que contienen escamas de plástico procedente de residuos post-industriales
}

\section{Study of mortars with industrial residual plastic scales}

\author{
OSCAR E. MAGARIÑOS ${ }^{1}$; CARLOS E. ALDERETE ${ }^{1}$; LUCÍA E. ARIAS ${ }^{1}$ y MARÍA E. LUCCA ${ }^{2}$ \\ Instituto de Tecnología Arquitectónica (ITA) Fac. de Arquitectura y Urbanismo -U. N. T. ${ }^{1}$ \\ Instituto de Microbiología, Fac. de Bioquímica, Química y Farmacia - U. N. T. ${ }^{2}$
}

Fecha de recepción: 7-I-97

Fecha de recepción: 19-VIII-97

ARGENTINA

\section{RESUMEN}

Este trabajo de investigación se desarrolla a partir de la hipótesis de utilizar los desechos post-industriales de PET (Tereftalato de Polietileno) como sustituto de áridos (arena), ingrediente de morteros, en la fabricación de componentes constructivos.

En dicho trabajo se estudian las propiedades fisico-quimicas de distintos morteros en los que se reemplazó el contenido de árido por escamas de plástico en distintas proporciones. Se compararon y evaluaron las propiedades fisico-mecánicas de los morteros en estudio con los convencionales mediante ensayos de resistencia a la flexión, compresión, absorción, durabilidad y microfotografias por barrido electrónico. Estos estudios determinaron que el agregado de PET en morteros puede ser usado como un posible sustituto de áridos, ya que se obtuvieron morteros con $66 \%$ de reemplazo de arena por escamas que presentaron menor peso unitario, absorción aceptable y resistencias acordes a las exigidas por normas.

\section{SUMMARY}

This work proposes the utilization of industrial residues of PET (Polyethylene Terephtalate) as a partial substitute of arids (sand) in mortar making for construction components. Therefore, the environmental impact of large volumes of plastic of urban residues could be decreased.

When PET scales were added to mortars in partial replacement of sand, lower unitary weight, acceptable absorption and resistances according to international specifications were achieved. Mortars with $66 \%$ of sand replacement by scales and without any additive, showed optimal characteristics to be used in concret block manufacturing.

\section{INTRODUCCIÓN}

La mayoría de los materiales plásticos que se fabrican, especialmente los destinados a la industria alimentaria para envases y embalajes, tienen como característica fundamental la resistencia al ataque microbiano lo que permite definirlos como no biodegradables. Por este motivo, si bien no son contaminantes directos, dificultan su recolección y disposición final, produciendo un impacto ambiental que conlleva a múltiples trastornos ecológicos. El tereftalato de polietileno (PET), es el

\section{INTRODUCTION}

Most plastic materials, specially those used in food industry must be resistant to microbial attack in order to constitute safe containers. Therefore they represent $a$ significative problem related to ecological impact when recollection and final disposition are analyzed. PET (Polyethylene Terepfhtalate) is used in bottling and packing of beverages, so the daily volume of this material after utilization is significant. Apart of this, defective industrial bottles are also discarded in the 
material plástico utilizado en la fabricación de envases y botellas de bebidas gaseosas, recipientes que son trados diariamente después de su utilización, generando grandes volúmenes de desechos. Por otro lado, todo el material defectuoso o sobrante de las fábricas de envases plásticos es reducido al estado de escamas o virutas para facilitar su almacenaje hasta su disposición final. El agregado de fibras plásticas de polipropileno y poliacrilato, de vidrio y de acero, fue estudiado por diferentes autores (1), con la finalidad de mejorar ciertas propiedades características de morteros y hormigones, como el control de la microfisuración superficial, mejorar la tenacidad, mayor tensión de flexión,entre otras. Pero como el material elegido en este trabajo (PET), no presenta la forma de fibras sino de escamas o virutas, se decidió utilizarlas como reemplazo del árido fino natural convencional (arena), no encontrándose material bibliográfico al respecto.

\section{MATERIALES Y MÉTODOS}

\section{Áridos naturales}

Los siguientes resultados fueron extraidos del estudio sobre áridos naturales utilizados en la ciudad de San Miguel de Tucumán, realizados en el LEME, en el año 1995 (2) (Tablas 1 y 2).

\section{Aglomerante}

El aglomerante utilizado es cemento portland normal, cuyos datos fueron provistos por la Fábrica Puesto Viejo de Juan Minetti S.A.(Tabla 3).

\section{Escamas de Pet}

El Tereftalato de Polietileno (PET) es un éster formado por condensación del ácido tereftálico (compuesto cuyo nombre es 1,4 benzeno dicarboxílico: $1,4-\mathrm{C}_{6} \mathrm{H}_{4}\left(\mathrm{CO}_{2} \mathrm{H}\right)_{2}$ form of scales or plastic shavings.

Addition of plastic fibers of polypropylene and polyacrilate, of glass and of steel were investigated by several authors (1) in order to improve specific properties of mortars and concrete. As example of the main characteristics to be considered one can name superficial microfisuration, tenacity and flexion. In this work, scaled and cleaned material provided by a local industry was used as a partial substitute of natural arids usually utilized in mortar making because of their lowest specific gravity. In future assays, the use of PET obtained from urban residues as an alternative way of plastic recycling would be studied. To our knowledge this is the first work where PET scales and not fibers were used.

\section{MATERIALS AND METHODS}

\section{Natural aggregates}

Sand extracted from a local quarry was used in the experimental assays and its characteristics are in tables 1 and 2 (LEME 1995 (2)).

\section{Binder}

The binder used was normal portland cement provided and tested by the manufacturing unit in Puesto Viejo, Juan Minetti, S.A. (Table 3).

\section{Pet scales}

Polyethylene Terephtalate (PET) is an aster formed by condensation of terephtalic acid, 1,4- $\mathrm{C}_{6} \mathrm{H}_{4}\left(\mathrm{CO}_{2} \mathrm{H}\right)_{2}$,

TABLA 1 (TABLE 1)

IRAM: Instituto de Racionalización Argentino de Materiales, normas standard (Granulometric Composition (IRAM))

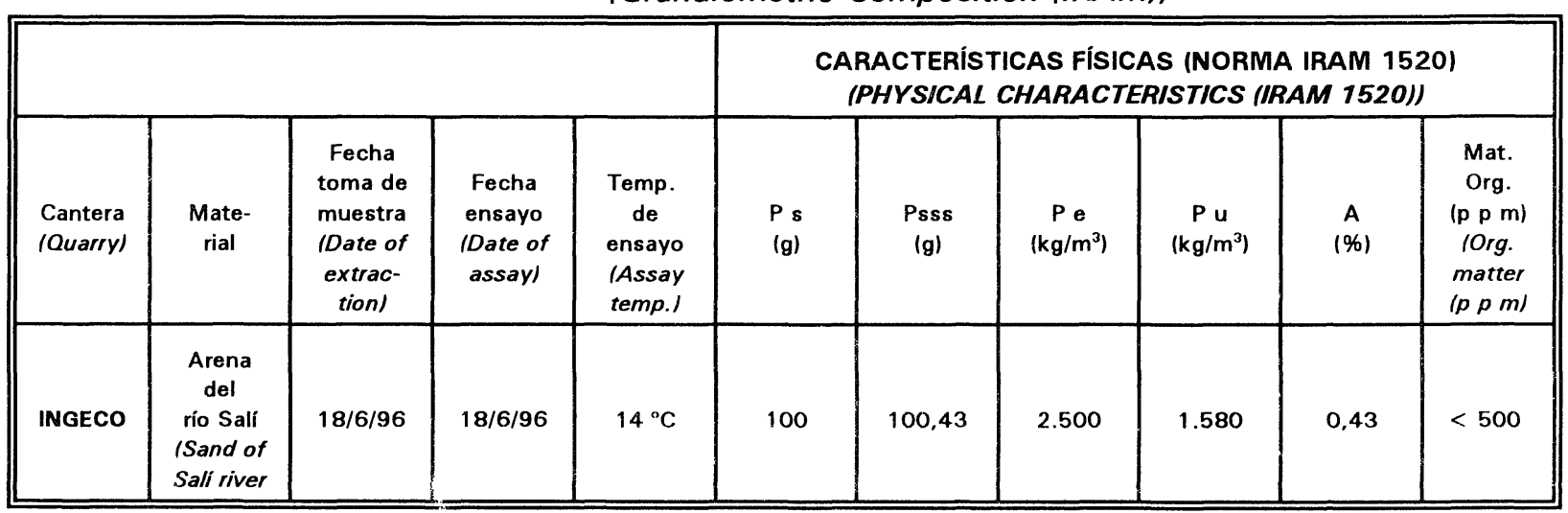


TABLA 2 (TABLE 2)

\begin{tabular}{|c|c|c|c|}
\hline COMPOSICIÓN G & MÉTRICA INORMA IRAI & SANULOMETRI & TION (IRAM 1627) \\
\hline \multicolumn{4}{|l|}{$\mathrm{Pm}=900 \mathrm{~g}$} \\
\hline $\begin{array}{l}\text { Tamiz } \\
\text { (Sieve) }\end{array}$ & $\begin{array}{l}\text { Peso Retenido }(g) \\
\text { (Ratained Weight (g)) }\end{array}$ & $\begin{array}{l}\% \text { Retenido } \\
\text { (\% Retained) }\end{array}$ & $\begin{array}{l}\text { \% Ret. Acumulados } \\
\text { (\% Ret. Accumulated) }\end{array}$ \\
\hline $4=4,75 \mathrm{~mm}$ & 2,5 & 0,278 & 0,278 \\
\hline $8=2,40 \mathrm{~mm}$ & 97,0 & 10,790 & 11,068 \\
\hline $16=1,20 \mathrm{~mm}$ & 191,5 & 21,301 & 32,370 \\
\hline $30=0,59 \mathrm{~mm}$ & 297,0 & 33,037 & 65,410 \\
\hline $50=0,29 \mathrm{~mm}$ & 236,0 & 26,250 & 91,660 \\
\hline $100=0,15 \mathrm{~mm}$ & 56,0 & 6,220 & 97,880 \\
\hline \multirow[t]{2}{*}{ Fondo (Botton) } & 19,0 & --- & --- \\
\hline & & & $M F=2,99$ \\
\hline
\end{tabular}

TABLA 3 (TABLE 3)

\begin{tabular}{|c|c|c|}
\hline \multicolumn{3}{|c|}{$\begin{array}{l}\text { CARACTERÍSTICAS FÍSICO-MECÁNICAS DEL CEMENTO } \\
\text { (PHYSICAL AND MECHANICAL CHARACTERISTICS OF CEMENT) }\end{array}$} \\
\hline Determinación (Determination) & Valor (Value) & Desviación (Deviation) \\
\hline Retenido \# $74 \mu$ (Retained $74 \mu$ ) & $3,89 \%$ & 0,20 \\
\hline Retenido \# $32 \mu$ (Retained $32 \mu$ ) & $27,9 \%$ & 0,90 \\
\hline S.E.B. & $3.324 \mathrm{~cm}^{2} / \mathrm{g}$ & 43,00 \\
\hline $\mathrm{H}_{2} \mathrm{O}$ de pasta $\left(\mathrm{H}_{2} \mathrm{O}\right.$ of paste $)$ & $24,1 \%$ & 0,20 \\
\hline Frguado inicial (Initial setting) & 2,50 hs. & -- \\
\hline Fraguado final (Final setting) & 5,03 hs. & --- \\
\hline Expansión (Expansion) & $0,09 \%$ & 0,001 \\
\hline Densidad (Density) & $3,15 \mathrm{~g} / \mathrm{cm}^{3}$ & 0,002 \\
\hline Flexión 1 día (Flexion 1 day) & $2,4 \mathrm{MPa}$ & 2,10 \\
\hline $\begin{array}{l}\text { Compresión } 1 \text { día } \\
\text { (Compression } 1 \text { day) }\end{array}$ & $8,5 \mathrm{MPa}$ & 5,60 \\
\hline Flexión 7 días (Flexion 7 days) & $6,2 \mathrm{MPa}$ & 4,4 \\
\hline $\begin{array}{l}\text { Compresión } 7 \text { días } \\
\text { (Compression } 7 \text { days) }\end{array}$ & $33,3 \mathrm{MPa}$ & 17,00 \\
\hline Flexión 28 días (Flexion 28 days) & $7,8 \mathrm{MPa}$ & 3,90 \\
\hline $\begin{array}{l}\text { Compresión } 28 \text { días } \\
\text { (Compression } 28 \text { days) }\end{array}$ & $45,1 \mathrm{MPa}$ & 19,00 \\
\hline
\end{tabular}


con un polímero de etileno $\left(\mathrm{CH}_{2}=\mathrm{CH}_{2}\right)_{\mathrm{n}}$, resina plástica derivada del petróleo, cuyas características se observan en la tabla 4 (3). with a polymer of ethylene, $\left(\mathrm{CO}_{2}=\mathrm{CH}_{2}\right)_{n}$, a plastic resin from petroletm, the polymer characteristics are shown in table $4(3)$.

TABLA 4 (TABLE 4)

\begin{tabular}{|c|c|c|c|c|}
\hline & $\begin{array}{c}\text { Clase } \\
\text { (Closs) } \\
\text { Tipo de Resistencia } \\
\text { (Type of Resin) } \\
\text { Sub Clase } \\
\text { (Sub Class) }\end{array}$ & $\begin{array}{l}\text { Polietileno } \\
\text { (Polyethylene) } \\
\text { Termoplástico } \\
\text { (Thormoplastic) } \\
\text { Baja densidad } \\
\text { (Low density) }\end{array}$ & $\begin{array}{c}\text { Polietileno } \\
\text { Pohyathyiene) } \\
\text { Termoplástico } \\
\text { (Thormoplestic) } \\
\text { Media densidad } \\
\text { (Medium density) }\end{array}$ & $\begin{array}{l}\text { Polietileno } \\
\text { (Polyethylene) } \\
\text { Tarmoplástico } \\
\text { (Therrmoplastic) } \\
\text { Alta densidad } \\
\text { (High density) }\end{array}$ \\
\hline & $\begin{array}{l}\text { Formas disponibles } \\
\text { (Available shapes) }\end{array}$ & $\begin{array}{c}\text { Polículas, Polvo, } \\
\text { Escamas, Tubos, } \\
\text { Monofilamentos, } \\
\text { Láminas, Granos, } \\
\text { Perlas } \\
\text { (Fiims, Dust, Scaíes, } \\
\text { Filaments, Grains, } \\
\text { Pearls) }\end{array}$ & Idem & $\begin{array}{l}\text { idem + fibra } \\
\text { (idem + fiber) }\end{array}$ \\
\hline 1 & $\begin{array}{l}\text { Propiedades oléctricas } \\
\text { (Eloctric properties) } \\
\text { Resistividad ohm } \times \mathrm{cm} \\
\text { (Resistivity ohm } \times \mathrm{cm} \text { ) } \\
\text { Constante dieléctrica } 60 \text { pcs } \\
\text { (Dielectric Constant } 60 \text { pcs) } \\
\text { Factor disipación } 60 \mathrm{cps} \\
\text { (Dissipation factor } 60 \mathrm{cps} \text { ) }\end{array}$ & $\begin{array}{c}>10^{15} \\
2,3 \\
<0,0005\end{array}$ & $\begin{array}{c}>10^{15} \\
2,3 \\
<0,0005\end{array}$ & $\begin{array}{c}>10^{15} \\
2,3 \\
<0,0005\end{array}$ \\
\hline 2 & $\begin{array}{l}\text { Propiedades mocánicas } \\
\text { (Mechanical properties) } \\
\text { Elasticidad } 10^{3} \mathrm{psi} \\
\text { (Elasticity } 10^{3} \text { psi) } \\
\text { Fuerza tensión psi } \\
\text { (Tension strength psi) } \\
\% \text { de elongación } \\
1 \% \text { of elongation) } \\
\text { Peso específico } \mathrm{g} / \mathrm{cm}^{3} \\
\text { (Specific gravity } \mathrm{g} / \mathrm{cm}^{3} \text { ) }\end{array}$ & $\begin{array}{c}14-38 \\
1.000-1.400 \\
400-700 \\
0,910-0,925\end{array}$ & $\begin{array}{c}35-90 \\
1.200-3.500 \\
1.500-2.600 \\
0,926-0,941\end{array}$ & $\begin{array}{c}85-160 \\
3.100-5.500 \\
2.400-5.000 \\
0.941-0,965\end{array}$ \\
\hline 3 & $\begin{array}{l}\text { Propiedades térmicas } \\
\text { (Thermal properties) } \\
\text { Velocidad de quemado } \\
\text { (Velocity of burning) } \\
\text { Calor específico cal/g } \\
\text { (Specific heat cal/g) } \\
\text { Coef. Exp. Lineal Térmico } 10^{.5}{ }^{\circ} \mathrm{C} \\
\text { (Lineal thermal Exp. Coef. } 10^{5 \circ} \mathrm{C} \text { ) } \\
\text { Máxima temperatura de uso }{ }^{\circ} \mathrm{C} \\
\text { (Maximal temp. of use }{ }^{\circ} \mathrm{C} \text { ) }\end{array}$ & $\begin{array}{c}\text { Muy lenta } \\
\text { (Very slow) } \\
0.55 \\
10-20 \\
60-70\end{array}$ & $\begin{array}{l}\text { Lenta } \\
\text { (S/ow) } \\
0,55 \\
14-16 \\
71-93\end{array}$ & $\begin{array}{l}\text { Lenta } \\
\text { (Slow) } \\
0,55 \\
11-13 \\
92-200\end{array}$ \\
\hline 4 & $\begin{array}{r}\text { Propiedades químicas } \\
\text { (Chemical properties) } \\
\text { Resistencia a: (Resistance to:) } \\
\text { Alcoholes (Alcohols) } \\
\text { Ácidos débiles y fuertes } \\
\text { (Weak and strong acids) } \\
\text { Álcalis débiles y fuertes } \\
\text { (Weak and strong bases) } \\
\text { Esteres (Esters) } \\
\text { Aceites (Oils) } \\
\text { Cetonas (Cetones) }\end{array}$ & $\begin{array}{c}\text { Variable } \\
\text { Buena } \\
\text { (Good) } \\
\text { Buena } \\
\text { (Good) } \\
\text { Mala (Bad) } \\
\text { Buena (Good) } \\
\text { Variable } \\
\end{array}$ & $\begin{array}{c}\text { Variable } \\
\text { Excelente } \\
\text { (Excellent) } \\
\text { Excelente } \\
\text { (Excellent) } \\
\text { Mala (Bad) } \\
\text { Excelente' (Excellent) } \\
\text { Variable }\end{array}$ & $\begin{array}{l}\text { Variable } \\
\text { Excelente } \\
\text { (Excellent) } \\
\text { Excelente } \\
\text { (Excellent) } \\
\text { Mala (Bad) } \\
\text { Buena (Good) } \\
\text { Variable }\end{array}$ \\
\hline 5 & $\begin{array}{l}\text { Aspecto } \\
\text { (Aspect) } \\
\text { Color } \\
\text { (Color) } \\
\text { Indice de Referencia } \\
\text { (Refraction index) }\end{array}$ & $\begin{array}{c}\text { Traslúcido } \\
\text { (Trans/ucent) } \\
\text { Incoloro } \\
\text { (Colorless) } \\
1,50-1,54\end{array}$ & $\begin{array}{c}\text { Traslúcido } \\
\text { (Trans/ucent) } \\
\text { Incoloro } \\
\text { (Colorless) } \\
1,52-1,54\end{array}$ & $\begin{array}{l}\text { Traslúcido } \\
\text { (Translucent) } \\
\text { Incoloro } \\
\text { (Colorless) } \\
1,54\end{array}$ \\
\hline
\end{tabular}


Las escamas de PET se caracterizan por su bajo peso específico y su alta resistencia frente a medios alcalinos; son suficientemente termoestables respecto a los requerimientos exigidos en la preparación de los morteros, poseen alta resistencia a la tracción y propiedades de elongación satisfactorias. El material PET fue provisto por una fábrica de envases plásticos, cuyos desechos post-industriales son reducidos a escamas (Tablas 5 y 6 ).
PET scales are characterized by the low specific gravity, resistance to basic media, enough thermostable as mortars making requires. It must be pointed out the high resistance to traction and good elongation properties of the scales. The PET used in this work was provided by a local plastic bottle factory where defective or excess production is converted into scales (Tables 5,6).

TABLA 5 (TABLA 5)

\begin{tabular}{|c|c|c|c|c|c|c|c|c|c|}
\hline \multirow{3}{*}{$\begin{array}{l}\text { Empresa } \\
\text { (Factory) }\end{array}$} & \multirow{3}{*}{ Material } & \multirow{3}{*}{$\begin{array}{c}\text { Fecha } \\
\text { toma de } \\
\text { muestras } \\
\text { (Date of } \\
\text { Collec- } \\
\text { tion) }\end{array}$} & \multirow{3}{*}{$\begin{array}{l}\text { Fecha } \\
\text { de } \\
\text { ensayo } \\
\text { (Date of } \\
\text { assay) }\end{array}$} & \multirow{3}{*}{$\begin{array}{c}\text { Temp. de } \\
\text { ensayo } \\
\text { (Assay } \\
\text { temp.) }\end{array}$} & \multicolumn{5}{|c|}{$\begin{array}{l}\text { CARACTERÍSTICAS FÍSICAS (NORMA IRAM 1520) } \\
\text { (PHYS/CAL CHARACTERISTICS (IRAM 1520) }\end{array}$} \\
\hline & & & & & \multirow{2}{*}{$\begin{array}{l}\text { P s } \\
\text { (g) }\end{array}$} & \multirow{2}{*}{$\begin{array}{c}P_{e} \\
\left(\mathbf{k g} / \mathbf{m}^{3}\right)\end{array}$} & \multicolumn{2}{|c|}{$P u\left(\mathbf{k g} / \mathbf{m}^{3}\right)$} & \multirow{2}{*}{$\begin{array}{l}\text { A } \\
(\%)\end{array}$} \\
\hline & & & & & & & $\begin{array}{c}\text { Sin } \\
\text { compactar } \\
\text { (Not com- } \\
\text { pacted) }\end{array}$ & $\begin{array}{l}\text { Compac- } \\
\text { tado } \\
\text { (compac- } \\
\text { ted) }\end{array}$ & \\
\hline $\begin{array}{c}\text { Envases } \\
\text { plásticos } \\
\text { S.A.I.Y.C } \\
\text { (Plastic } \\
\text { bottle) } \\
\text { S.A.I.Y.C }\end{array}$ & PET & $18 / 6 / 96$ & 28/6/96 & $11^{\circ} \mathrm{C}$ & 100 & 1.200 & 416,8 & 482,1 & 0 \\
\hline
\end{tabular}

TABLA 6 (TABLE 6)

\begin{tabular}{|c|c|c|c|}
\hline \multicolumn{4}{|c|}{ COMPOSICIÓN GRANULOMÉTRICA (NORMA IRAM 1627) (GRANULOMETRIC COMPOSITION (IRAM 1627)) } \\
\hline \multicolumn{4}{|l|}{$\mathrm{Pm}=300 \mathrm{~g}$} \\
\hline $\begin{array}{l}\text { Tamiz } \\
\text { (Sieve) }\end{array}$ & $\begin{array}{l}\text { Peso retenido }(g) \\
\text { (Retained Weight }(g) \text { ) }\end{array}$ & $\begin{array}{l}\text { \% Retenido } \\
\text { (\% Retained) }\end{array}$ & $\begin{array}{l}\text { \% Ret. acumulados } \\
\text { (\% Ret. accumulated) }\end{array}$ \\
\hline $4=4,75 \mathrm{~mm}$ & 4 & 1,32 & 1,32 \\
\hline $8=2,40 \mathrm{~mm}$ & 232 & 76,53 & 77,88 \\
\hline $16=1,20 \mathrm{~mm}$ & 56 & 18,48 & 96,36 \\
\hline $30=0,59 \mathrm{~mm}$ & 7 & 2,31 & 98,67 \\
\hline $50=0,29 \mathrm{~mm}$ & 1 & 0,33 & 99,00 \\
\hline $100=0,15 \mathrm{~mm}$ & 0,5 & 0,08 & 99,08 \\
\hline $200=0,074 \mathrm{~mm}$ & 0,5 & 0,08 & 99,16 \\
\hline Fondo (Bottom) & --- & --- & -- \\
\hline & & & $M F=5.7$ \\
\hline
\end{tabular}




\section{Dosificaciones de las mezclas}

a) Porcentajes de reemplazo de árido por escamas

Se reemplazó un 33, 66 y 100\% del peso de arena utilizado en el mortero convencional por la cantidad de escamas equivalentes al volumen de arena reemplazado. Estos valores fueron seleccionados sobre un amplio rango $(0-100 \%$, con un incremento de $10 \%)$. Se observaron cambios significativos en los parámetros de control elegidos a partir de la mezcla, cuya composición contenía un $30 \%$ menos de arena y, en su lugar, $90 \mathrm{~kg}$ de escamas PET $/ \mathrm{m}^{3}$. A partir de este valor, para porcentajes mayores de reemplazo, la incorporación de plástico en la composición de la mezcla producía cambios en las características del mortero, no gradualmente proporcionales al incremento en el \% de escamas incorporadas, sino que se observaron modificaciones apreciables para porcentajes específicos de agregado de PET.

Se decidió reemplazar $1 / 3,2 / 3$ y $3 / 3$ del peso del árido (33, 66 y $100 \%$ ) del mortero patrón que corresponden a 300600 y $900 \mathrm{~kg}$ arena/m $/ \mathrm{m}^{3}$, por 91,182 y $274 \mathrm{~kg} / \mathrm{m}^{3}$, diferencia que surge de los diferentes pesos unitarios (pesos específicos aparentes) de cada uno de los materiales para mantener constante el volumen aparente que es sustituido en la mezcla al cambiar arena por escamas.

\section{b) Relación agua/cemento (W)}

Se fijó en $0,50,0,40$ y 0,34 para mezclas sin aditivos y en 0,25 y 0,30 para mezclas con aditivos, respectivamente.

\section{c) Aditivos}

Se utilizaron aditivos de Sika, superfluidificante (Sikament N) y plastificante (Plastiment BV), agregados a las mezclas, según las dosificaciones usuales.

Se adoptó una relación en peso de una parte de cemento por tres de áridos (1:3) y $300 \mathrm{~kg}$ cemento $/ \mathrm{m}^{3}$ mezcla. Las escamas de PET fueron agregadas en distintos porcentajes de acuerdo a la porción de arena que desea reemplazarse: $0,33,66$ y $100 \%$. Debido a la diferencia de peso unitario entre el árido y las escamas, se reemplazó el PET por un volumen aparente equivalente al del árido a sustituir (Tabla 7).

\section{Preparación de los morteros}

Se moldearon 9 probetas de $40 \times 40 \times 160 \mathrm{~mm}\left(254 \mathrm{~cm}^{3}\right)$ por cada mezcla o dosificación propuesta, de las cuales se

\section{Mixtures dosages:}

\section{a) Percentages of sand replacement by PET scales}

33, 66 and $100 \%$ of the sand weight used in the conventional mortar was replaced by the PET scales necessary to obtain the same apparent volume of the removed arid. These values were selected from a wide range of points $(0-100 \%$ in $10 \%$ increments) assayed. Significative changes in the chosen control parameters where found when the mixture had at least, a $30 \%$ less of sand replaced by $90 \mathrm{~kg} P E T \mathrm{~m}^{3}$ cement. For further increases in the replacement percentages, the added plastic produced changes in the mortar characteristics but the effects observed were not gradually proportional to the increase of replacement. So the mixtures dosages with showed clearly the influence of PET scales were selected.

The mixtures were performed replacing $1 / 3,2 / 3$ and $3 / 3$ of sand weight $(33,66$ y $100 \%)$ used in the conventional mortar (300, 600 and $900 \mathrm{~kg} \mathrm{sand} / \mathrm{m}^{3}$ cement) by 91, 182 and $274 \mathrm{~kg} \mathrm{PET} / \mathrm{m}^{3}$ cement. Differences in both material weights used were due to their different unit weights (apparent specific gravities) taking in account the fact that the apparent volume replaced in the mixture should be kept constant.

\section{b) Water/cement ratio $(W)$}

Was fixed at 0.50, 0.40 and 0.34 in the mixtures without any additives and 0.25 and 0.30 in the mixtures with additives, respectively.

\section{c) Additives}

The additives were purchased from Sika. The superfluidizer (Sikament $N$ ) and the plasticizer (Plastiment BV) were added to the mixtures according to standard values.

The ratio used in the mixture preparation was one part of cement and three of arids (1:3) and $300 \mathrm{~kg} \mathrm{cement} / \mathrm{m}^{3}$ mixture. PET scales were added in different percentages corresponding to the desired portion of sand to be replaced: 0, 33, 66 and $100 \%$. Due to the difference in sand and scales unit weights, percentages were referred to apparent volume of both (Table 7).

\section{Mortar making procedure}

9 test cylinders of $40 \times 40 \times 160 \mathrm{~mm}\left(254 \mathrm{~cm}^{3}\right)$ for each dosage proposed were done. 4 of them were analyzed at the 
TABLA 7 (TABLE 7)

\begin{tabular}{|c|c|c|c|c|c|c|c|}
\hline $\begin{array}{c}\text { Serie } \\
\text { de } \\
\text { probetas } \\
\text { (Series of } \\
\text { test } \\
\text { cylinders) }\end{array}$ & $\begin{array}{c}\% \\
\text { Sustitución } \\
\text { de arena } \\
\text { por PET } \\
\text { (\% of } \\
\text { Replecement } \\
\text { of sand } \\
\text { by PET) }\end{array}$ & $\begin{array}{c}\text { Cemento } \\
\text { (Cement) } \\
\mathrm{kg} / \mathrm{m}^{3}\end{array}$ & $\begin{array}{l}\begin{array}{l}\text { Arena } \\
\text { (Sand) }\end{array} \\
\mathrm{kg} / \mathrm{m}^{3}\end{array}$ & $\begin{array}{c}\text { Escamas de } \\
\text { PET } \\
\text { (PET } \\
\text { scales) } \\
\\
\mathrm{kg} / \mathrm{m}^{3}\end{array}$ & $\begin{array}{c}\begin{array}{c}\text { Agua } \\
\text { (Water) }\end{array} \\
\text { Litros (Liter) }\end{array}$ & $\begin{array}{c}\text { W } \\
\text { Relación } \\
\text { agua/cemento } \\
\text { (water/coment } \\
\text { Ratio) } \\
\text { (w,w) }\end{array}$ & $\begin{array}{l}\text { Aditivo } \\
\text { (Additive) } \\
\%(w, w)\end{array}$ \\
\hline \multirow{4}{*}{1} & $\begin{array}{c}\text { Patrón } \\
0 \% \\
\text { (Control } \\
\text { O\%) }\end{array}$ & \multirow{4}{*}{300} & 900 & 0 & \multirow{4}{*}{150} & \multirow{4}{*}{0,50} & \multirow{12}{*}{$\begin{array}{c}\text { No } \\
\text { contiene } \\
\text { (No } \\
\text { additives) }\end{array}$} \\
\hline & $33 \%$ & & 600 & 91,53 & & & \\
\hline & $66 \%$ & & 300 & 183,06 & & & \\
\hline & $100 \%$ & & 0 & 274,59 & & & \\
\hline \multirow{4}{*}{2} & $\begin{array}{c}\text { Patrón 0\% } \\
\text { (Control } \\
0 \% \text { ) }\end{array}$ & \multirow{4}{*}{300} & 900 & 0 & \multirow{4}{*}{120} & \multirow{4}{*}{0,40} & \\
\hline & $33 \%$ & & 600 & 91,53 & & & \\
\hline & $66 \%$ & & 300 & 183,06 & & & \\
\hline & $100 \%$ & & 0 & 274,59 & & & \\
\hline \multirow{4}{*}{3} & $\begin{array}{c}\text { Patrón } \\
0 \% \\
\text { (Control } \\
0 \% \text { ) }\end{array}$ & \multirow{4}{*}{300} & 900 & 0 & \multirow{4}{*}{102} & \multirow{4}{*}{0,34} & \\
\hline & $33 \%$ & & 600 & 91,53 & & & \\
\hline & $66 \%$ & & 300 & 183,06 & & & \\
\hline & $100 \%$ & & 0 & 274,59 & & & \\
\hline \multirow{4}{*}{4} & $\begin{array}{c}\text { Patrón 0\% } \\
\text { (Control } \\
0 \% \text { | }\end{array}$ & \multirow{4}{*}{300} & 900 & 0 & \multirow{4}{*}{75} & \multirow{4}{*}{0,25} & \multirow{4}{*}{$\begin{array}{c}2,0 \\
\text { Super } \\
\text { fluidificante } \\
(2.0 \\
\text { Super } \\
\text { fluidizer) }\end{array}$} \\
\hline & $33 \%$ & & 600 & 91,53 & & & \\
\hline & $66 \%$ & & 300 & 183,06 & & & \\
\hline & $100 \%$ & & 0 & 274,59 & & & \\
\hline \multirow{4}{*}{5} & $\begin{array}{c}\text { Patrón } \\
0 \% \\
\text { (Control } \\
\text { O\%) }\end{array}$ & \multirow{4}{*}{300} & 900 & 0 & \multirow{4}{*}{90} & \multirow{4}{*}{0,30} & \multirow{4}{*}{$\begin{array}{c}0,5 \\
\text { Plastificante } \\
10.5 \\
\text { Plasticizer }\end{array}$} \\
\hline & $33 \%$ & & 600 & 91,53 & & & \\
\hline & $66 \%$ & & 300 & 183,06 & & & \\
\hline & $100 \%$ & & 0 & 274,59 & & & \\
\hline
\end{tabular}


analizaron 4 muestras a la edad de 7 días y 4 muestras a la edad de 28 días, para ensayos de resistencia a flexión y compresión en ambos casos, utilizándose, la probeta restante, para determinar la absorción. El método de mezclado, llenado de moldes y compactación se realizó según indica la norma IRAM 1622. En todos los casos se determinó previamente, en estado fresco, la fluidez, por mesa de asentamiento "Flow Table", Norma IRAM $1570 / 55$ y el peso unitario de las muestras.

\section{Estudios de durabilidad por el Método de Ensayo Acelerado de la Barra de Mortero (NBRI)}

Estos estudios fueron realizados de acuerdo a la Norma IRAM 1637 o su equivalente ASTM C 227- 90, la norma de ensayo ASTM C 1260-94 o método canadiense del prisma de hormigón (CSA A23.2-25A).

\section{Metodología del ensayo}

El método consiste en someter probetas de mortero a un curado acelerado en solución de $\mathrm{NaOH}$ a $80^{\circ} \mathrm{C}$, midiendo los cambios dimensionales en el tiempo.

La confección de las probetas se realizó siguiendo los lineamientos de la Norma ASTM C 227-90, en lo que respeta a las dimensiones de las barras $(25 \times 25 \times 285 \mathrm{~mm})$.

Los morteros empleados fueron realizadas en laboratorio a base de cemento portland normal y arena del río Salí.

El cemento utilizado es portland normal (Tabla 5). Se usaron probetas de mortero-patrón con $\mathrm{W}=0,40 \mathrm{y}$ mortero-PET con $\mathrm{W}=0,40$ y $66 \%$ de escamas (equivalente al volumen reemplazado de arena), moldeando tres probetas para cada ensayo.

Durante las primeras 24 horas se curan en cámara húmeda a $23 \pm 2{ }^{\circ} \mathrm{C}$ y más del $95 \%$ de humedad relativa. A las 24 horas, se desmoldan las barras y se sumergen en agua, en recipiente cerrado, colocándolas en estufa a $80 \pm 2{ }^{\circ} \mathrm{C}$ durante 24 horas más. A las 48 horas del moldeo se realiza la lectura inicial de cada barra, en ambiente de laboratorio $23 \pm 2{ }^{\circ} \mathrm{C}$. Una vez obtenida y registrada la lectura inicial, las barras se sumergen en solución de $1 \mathrm{~N} \mathrm{NaOH} \mathrm{a} 80^{\circ} \mathrm{C}$, tomando la precaución que la relación de volumen de solución/volumen de barra sea igual a $4 \pm 0,5$. La determinación del cambio longitudinal se realiza posteriormente y en forma periódica, realizando las lecturas a temperatura y humedad constante del ambiente del laboratorio. Se realizaron tres lecturas intermedias durante 16 días.

\section{Estudios de interfase escama-pasta}

Estos estudios fueron realizados por barrido superficial por microscopía electrónica de alta resolución (SEM) con el age of 7 days and 4, at the age of 28 days, and resistances to flexion and compression were determined in both cases. Absorption was determined in the test cylinder number 9. Mixing, filling and compacting were done according to the IRAM 1622 norm. Fluidity was previously determined in the fresh state according to the "Flow Table" method (IRAM 1570/55). Unit weight of the resulting mortars were calculated.

\section{Durability assays for Mortar Bar Accelerated Assay (NBRI) Method}

These experiments were done according to IRAM 1637 norm or the equivalent ASTM C 227-90, ASTM C 1260-94 or Canadian method of concrete prism (CSA A23.2-25A).

Assay procedure

Test cylinders of mortars were subject to accelerated hardening in a solution of $1 \mathrm{~N} \mathrm{NaOH}$ at $80^{\circ} \mathrm{C}$ and dimensional changes were measured.

Test cylinders were prepared according to ASTM C 227-90 Norm $(25 \times 25 \times 285 \mathrm{~mm})$.

The mortars selected for this assay were (Table 5). The control mortar with $W=0.40$ and the PET-mortar with $W=0.40$ and $66 \%$ of replacement of sand weight by $a$ same volume of PET scales. Three test cylinders were prepared for each assay.

During the first 24 hours, hardening was performed in a wet chamber at $23 \pm 2{ }^{\circ} \mathrm{C}$ and $95 \%$ of relative humidity. After 24 hours, bars were submerged in water, using an hermetic recipient and putting them in an oven at $80 \pm 2{ }^{\circ} \mathrm{C}$ during $24 \mathrm{~h}$ more. After 48 hours of molding, initial lecture of each bar was done at a constant environmental temperature of $23 \pm 2{ }^{\circ} \mathrm{C}$. The bars were then submerged in a solution of $1 \mathrm{~N} \mathrm{NaOH}$ at $80^{\circ} \mathrm{C}$, (solution volume/bar volume ratio was kept constant at $4 \pm 0.5)$ and dimensional changes in mortars were periodically measured during 16 days at constant environmental temperature and humidity.

\section{Study of the interface scales}

These studies were performed using a scanning electron microscope of high resolution (SEM). The 
propósito de observar la interfase entre el mortero y la escama plástica. Las muestras estudiadas fueron realizadas en laboratorio a base de arena del río Salí (Tablas 3 y 4) y cemento portland normal (Tabla 5). Para ello se emplearon probetas de mortero-patrón con $\mathrm{W}=0,40$ y mortero-PET con $\mathrm{W}=0,40$ y $66 \%$ de escamas. Sobre algunas muestras se realizaron ensayos a flexión y compresión con el objeto de observar los cambios morfológicos cuando se aplicaban fuerzas externas.

Las muestras se analizaron para determinar:

a) Resistencia a la flexión a 7 y 28 días.

b) Resistencia a la compresión a 7 y 28 días.

c) Absorción (\%), fluidez y aspecto de las muestras.

d) Reactividad alcalina con $1 \mathrm{~N} \mathrm{NaOH}$ en estufa a $80^{\circ} \mathrm{C}$ durante 14 días.

e) Análisis de interfase por microscopía electrónica de barrido.

Definición de parámetros utilizados en la evaluación de los ensayos

$\mathbf{P}_{\mathbf{m}}=$ Peso de muestra en condiciones naturales.

$\mathbf{P}_{\mathrm{s}}=$ Peso seco de muestra a $110^{\circ} \mathrm{C}$ en estufa hasta peso constante.

Psss $=$ Peso de muestra sobresaturada y superficie seca.

Volumen aparente $=$ volumen real $($ parte sólida $)+$ volumen de vacíos (huecos o poros).

P.e. $=$ Peso específico absoluto $\left(\mathrm{kg} / \mathrm{m}^{3}\right)$, calculado con el volumen real sin considerar el volumen vacío.

P u. $=$ Peso unitario o Peso específico aparente $\left(\mathrm{kg} / \mathrm{m}^{3}\right)$, calculado con el volumen aparente.

Absorción $=(\mathrm{A} \%)$, es la cantidad de agua que absorbe la muestra seca hasta llegar al estado de sobresaturación y superficie seca y se expresa como porcentaje: $g$ de $\mathrm{H}_{2} \mathrm{O}$ absorbidos por cada $100 \mathrm{~g}$ de materia seca. studied samples were perforrned in the laboratory, using sand from Sali river (Tables 3 and 4) and ordinary portland cement (Table 5). The selected test cylinders were the control mortar with $W=0.40$ and the PET-mortar with $W=0.40$ and $66 \%$ of replacement. Same test cylinders were then used for resistances to flexion and compression assays in order to observe morphological changes when external forces were applied.

Samples were analyzed in order to determine

a) Flexural resistance at the age of 7 and 28 days.

b) Compressive resistance at the age of 7 and 28 days.

c) Absorption (\%), fluidity and aspect of mixtures.

d) Reactivity to bases with $1 \mathrm{~N} \mathrm{NaOH}$ at $80^{\circ} \mathrm{C}$ during 14 days.

e) Analysis of the interface by scanning electron microscopy.

Definitions of parameters utilized in the evaluation of the assays

$\boldsymbol{P}_{m}=$ Sample weight in natural conditions

$\boldsymbol{P}_{\mathrm{s}}=$ Sample dry weight at $110^{\circ} \mathrm{C}$ until constant weight.

Psss = Sample weight oversaturate and dry surface.

Apparent volume $=$ real volume (solid portion) + empty volume (holes and pores).

P.e. $=$ Absolute specific gravity $\left(\mathrm{kg} / \mathrm{m}^{3}\right)$ considering the real mortar volume..

$\boldsymbol{P}$ u. $=$ Unit weight or Apparent specific gravity $\left(\mathrm{kg} / \mathrm{m}^{3}\right)$ considering the apparent mortar volume.

Absorption $=(A \%)$, is the water that is absorbed by the dry sample until oversaturation and dry surface is attained. It is expressed as: $\mathrm{g} \mathrm{H}_{2} \mathrm{O}$ absorbed per $100 \mathrm{~g}$ of dry matter.

$$
\mathrm{A} \%=\frac{\text { Psss }-\mathrm{Ps}}{\mathrm{Ps}} \times 100
$$

MF = Módulo de finura es un número abstracto que permite identificar la granulometría de un agregado mediante la sumatoria de los \% retenidos acumulados en la serie normalizada de tamices y dividida en 100 , representando el tamaño medio de la partícula.
$M F=$ Module of fineness is an abstract number which allow to identify the granulation of the aggregate. It is expressed as \% retained accumulated in a standard series of sieve divided in 100, and it represents the size of the particles. 


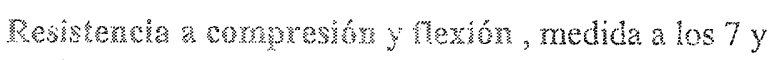
28 das en estado endurecido (on MPa)

Fiveluez $=f=c / d$ (c: extendido, d: diámetro de la base mayor cono).

Cohesividur, define el aspecto de la muestra.

\section{RESULTADOS y DISCUSIÓN}

Los valores de la tabla 8 se expresan en porcentajes referidos a los valores absolutos del mortero patrón que se indican en cada serie y que corresponden al $100 \%$, a fin de establecer cuál es el mortero más adecuado para luego ser analizado en forma particular.

En la determinación de las propiedades del mortero en estado fresco y endurecido, se observaron las siguientes características :

\section{Estado fresco}

Los morteros se presentaron poco plásticos y poco cohesivos para porcentajes de reemplazo de escamas superiores al $66 \%$ para las mezclas sin agregado de aditivos, lo que se acentuaba a medida que disminula la relación $\mathrm{W}$. La falta de docilidad y homogeneidad de la mezcla, provocaba una disminución del asentamiento (después de compactado) en correspondencia con el incremento del porcentaje de reemplazo, lo que equivale a una mayor porosidad final. La razón, a nuestro juicio, fue la inadecuada granulometría de las escamas de PET, otorgadas por la industria, ya que la curva de cribado no era extendida (Tabla 2), puesto que el $76 \%$ del material quedaba retenido en el tamiz $N^{\circ} 8(2,40 \mathrm{~mm})$.

En el ensayo de absorción se observa que analizando las series 1, 2, 3 y 4, para porcentajes similares de escamas de PET, la disminución de $\mathrm{W}$ produce una disminución en el \% absorción mientras que para una misma serie con $\mathrm{W}$ constante, el incremento del $\%$ PET en la mezcla produce un incremento de la absorción.

La serie 5, contiene $0,5 \%$ de plastificante y $\mathrm{W}=0,30$. Se observa un discreto aumento del \% absorción al cambiar de un 66 a un $100 \%$ de escamas, rango en el que las otras series muestran grandes variaciones. Analizando los resultados de la ya mencionada relación directamente proporcional entre $\mathrm{W}$ y $\%$ absorción, esta serie presenta valores más bajos de \% absorción que la serie 3 de $\mathrm{W}$ similar y con la serie 4 de $W=0,25$. El agregado de plastificante disminuye notablemente la absorción y mantiene la cohesividad de la me zcla aún en presencia de $66 \%$ o más de escamas (Figura 1).

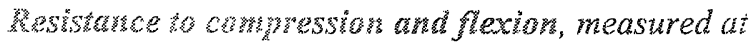
the age of 7 and 28 days in the hardened state (MPa).

Whumby $=f=c / d$ (c: extended sample, d: large cone base).

Cohesivity, defines the aspect of the mixture.

\section{RESULTS AND DISCUSSTON}

Values in table 8 were expressed as percentages referred to absolute values (100\%) corresponding to control mortars of each test cylinder series.

The properties of mortars observed in fresh and hardened states were the following:

\section{Frespstare}

Mortars were less plastic and less cohesive when the percentages of scales replacement were higher than $66 \%$ in the case of mixtures without any additive and this effect was increased when $W$ was decreased. Mixtures presented low docility and low homogeneity. Settlement before compacting decreased when the percentage of replacement of sand by scales was increased. The reason of this effect was probably due to a higher final porosity. This could be related to an inadequate granulation of the scales because the sifted curve obtained was not enough extended (Table 2). $76 \%$ of material remained in sieve mesh $N^{\circ} 8$ $(2.40 \mathrm{~mm})$.

It could be observed in series 1,2, 3 and 4, that, for similar percentages of scales added, a decrease of $W$ resulted in a decrease in \% of absorption. When each series with constant $W$ was analyzed, an increase in added PET was correlated to an increase in absorption.

Series 5 , with $0.5 \%$ of plasticizer added and $W=0.30$, presented a slight increase in the absorption when the percentage of replacement of sand by scales was changed from $66 \%$ to $100 \%$. For this range of PET replacement the other series of test cylinders showed significant variations. Taking in to account the direct proportionality between $W$ and \% absorption, results obtained in this series of mortars were lower than the corresponding to series 3 (with similar $W$ ) and series 4 (with $W=0.25$ ). Plasticizer addition decreased significantly the absorption and allowed to maintain cohesivity of the mixture even in presence of scales corresponding to $66 \%$ or more (Figure 1). 
TABLA 8 (TABLE 8)

Propiedades de los morteros en estado fresco y endurecido (Properties of mortars in fresh and hardened states)

\begin{tabular}{|c|c|c|c|c|c|c|c|c|c|}
\hline \multirow{3}{*}{. } & \multirow{3}{*}{ 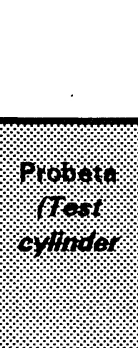 } & \multicolumn{3}{|c|}{ 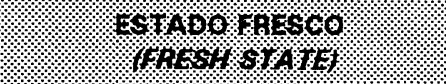 } & \multicolumn{5}{|c|}{ 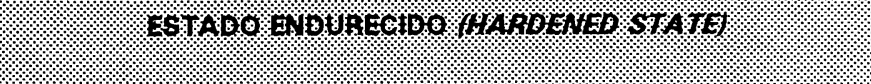 } \\
\hline & & \multirow[t]{2}{*}{ 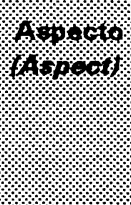 } & \multirow{2}{*}{$\frac{16}{110 \% 16}$} & \multirow{2}{*}{ 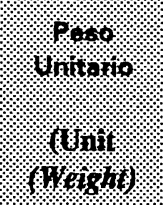 } & \multicolumn{2}{|c|}{ 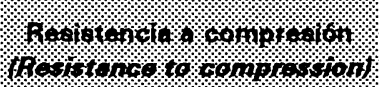 } & \multicolumn{2}{|c|}{ 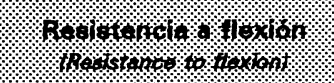 } & \multirow{2}{*}{ 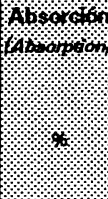 } \\
\hline & & & & & $10+1+1 \%$ & \%(2) & $19 \% \%$ & $108 \% 4 \%$ & \\
\hline \multirow{4}{*}{$\begin{array}{c}4^{2} \\
3_{1}\end{array}$} & $\begin{array}{l}\text { Patrón } \\
\text { (Control) }\end{array}$ & $\mathbf{A}$ & 1,35 & $\begin{array}{c}2.364 \mathrm{~kg} / \mathrm{m}^{3} \\
100 \%\end{array}$ & $\begin{array}{c}24,8 \mathrm{MPa} \\
100 \%\end{array}$ & $\begin{array}{c}37,7 \mathrm{MPa} \\
100 \%\end{array}$ & $\begin{array}{c}5,72 \mathrm{MPa} \\
100 \%\end{array}$ & $\begin{array}{c}8,90 \mathrm{MPa} \\
100 \%\end{array}$ & 8,58 \\
\hline & $33 \%$ & A & 1,42 & $75,13 \%$ & $79,60 \%$ & $80,00 \%$ & $99,00 \%$ & $92,00 \%$ & 10,76 \\
\hline & $66 \%$ & B & 1,25 & $66,92 \%$ & $40,76 \%$ & $42,40 \%$ & $52,55 \%$ & $48,21 \%$ & 15,78 \\
\hline & $100 \%$ & B & 1,05 & $53,64 \%$ & $18,34 \%$ & $21,12 \%$ & $35,32 \%$ & $32,20 \%$ & 29,87 \\
\hline \multirow{4}{*}{ 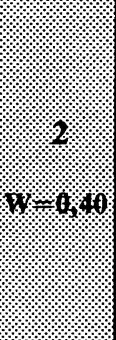 } & $\begin{array}{l}\text { Patrón } \\
\text { (Control) }\end{array}$ & $\mathbf{A}$ & 1,20 & $\begin{array}{c}2.386 \mathrm{~kg} / \mathrm{m}^{3} \\
100 \%\end{array}$ & $\begin{array}{c}28,2 \mathrm{MPa} \\
100 \%\end{array}$ & $\begin{array}{c}46,4 \mathrm{MPa} \\
100 \%\end{array}$ & $\begin{array}{c}7,00 \mathrm{MPa} \\
100 \%\end{array}$ & $\begin{array}{c}8,04 \mathrm{MPa} \\
100\end{array}$ & 7,24 \\
\hline & $33 \%$ & $\mathbf{A}$ & 1,25 & $91,60 \%$ & $88,70 \%$ & $100 \%$ & $88,00 \%$ & 111,56 & 9,35 \\
\hline & $66 \%$ & B & 1,20 & $65,82 \%$ & $34,36 \%$ & $50,54 \%$ & $44,83 \%$ & 45,29 & 12,89 \\
\hline & $100 \%$ & B & 1,45 & $45,42 \%$ & $11,02 \%$ & $7,65 \%$ & $27,25 \%$ & 23,51 & 26,14 \\
\hline \multirow{4}{*}{ א. } & $\begin{array}{l}\text { Patrón } \\
\text { (Control) }\end{array}$ & A & 1,18 & $\begin{array}{c}2.230 \mathrm{~kg} / \mathrm{m}^{3} \\
100 \%\end{array}$ & $\begin{array}{c}28,72 \mathrm{MPa} \\
100 \%\end{array}$ & $\begin{array}{c}41,44 \mathrm{MPa} \\
100 \%\end{array}$ & $\begin{array}{c}5,72 \mathrm{MPa} \\
100 \%\end{array}$ & $\begin{array}{c}4,96 \mathrm{MPa} \\
100 \%\end{array}$ & 6,30 \\
\hline & $33 \%$ & A & 1,20 & $88,75 \%$ & $89,66 \%$ & $60,59 \%$ & $76,23 \%$ & $72,43 \%$ & 8,03 \\
\hline & $66 \%$ & B & 1,20 & $70,27 \%$ & $35,44 \%$ & $36,99 \%$ & $55,33 \%$ & $55,58 \%$ & 12,25 \\
\hline & $100 \%$ & B & 1,21 & $48,83 \%$ & $9,29 \%$ & $10,60 \%$ & $23,96 \%$ & $23,00 \%$ & 22,82 \\
\hline \multirow{4}{*}{ \% } & $\begin{array}{l}\text { Patrón } \\
\text { (Control) }\end{array}$ & A & 1,67 & $\begin{array}{c}2.044 \mathrm{~kg} / \mathrm{m}^{3} \\
100 \%\end{array}$ & $\begin{array}{c}16,75 \mathrm{MPa} \\
100 \%\end{array}$ & $\begin{array}{c}27,89 \mathrm{MPa} \\
100 \%\end{array}$ & $\begin{array}{c}4,58 \mathrm{MPa} \\
100 \%\end{array}$ & $\begin{array}{c}5,95 \mathrm{MPa} \\
100 \%\end{array}$ & 5,95 \\
\hline & $33 \%$ & A & 1,62 & $90,93 \%$ & $67,70 \%$ & $49,67 \%$ & $79,00 \%$ & $72,00 \%$ & 7,96 \\
\hline & $66 \%$ & A & 1,62 & $68,05 \%$ & $39,36 \%$ & $29,53 \%$ & $59,32 \%$ & $43,29 \%$ & 10,05 \\
\hline & $100 \%$ & A & 1,63 & $49,41 \%$ & $9,73 \%$ & $10,00 \%$ & -- & -- & 18,04 \\
\hline \multirow{4}{*}{ 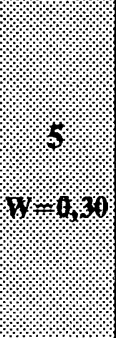 } & $\begin{array}{l}\text { Patrón } \\
\text { (Control) }\end{array}$ & A & 1,50 & $\begin{array}{c}2.337 \mathrm{~kg} / \mathrm{m}^{3} \\
100 \%\end{array}$ & $\begin{array}{c}52,18 \mathrm{MPa} \\
100 \%\end{array}$ & $\begin{array}{c}59,25 \mathrm{MPa} \\
100 \%\end{array}$ & $\begin{array}{c}7,24 \mathrm{MPa} \\
100 \%\end{array}$ & $\begin{array}{c}7,24 \mathrm{Mpa} \\
100 \%\end{array}$ & 5,20 \\
\hline & $33 \%$ & A & 1,68 & $83,68 \%$ & $48,30 \%$ & $62,79 \%$ & $61,41 \%$ & - & 7,88 \\
\hline & $66 \%$ & A & 1,72 & $54,93 \%$ & $10,64 \%$ & $19,08 \%$ & $25,88 \%$ & $\ldots$ & 8,99 \\
\hline & $100 \%$ & A & -- & $38,35 \%$ & $4,021 \%$ & $9,58 \%$ & $9,80 \%$ & -- & 13,10 \\
\hline
\end{tabular}

NOTA: $A=$ mortero de aspecto cohesivo normal NOTE: $A=$ mortar with normal cohesivity
$B=$ mortero de aspecto poco cohesivo, suelto y disgregado

$B=$ mortar with less cohesivity and not aggregated 


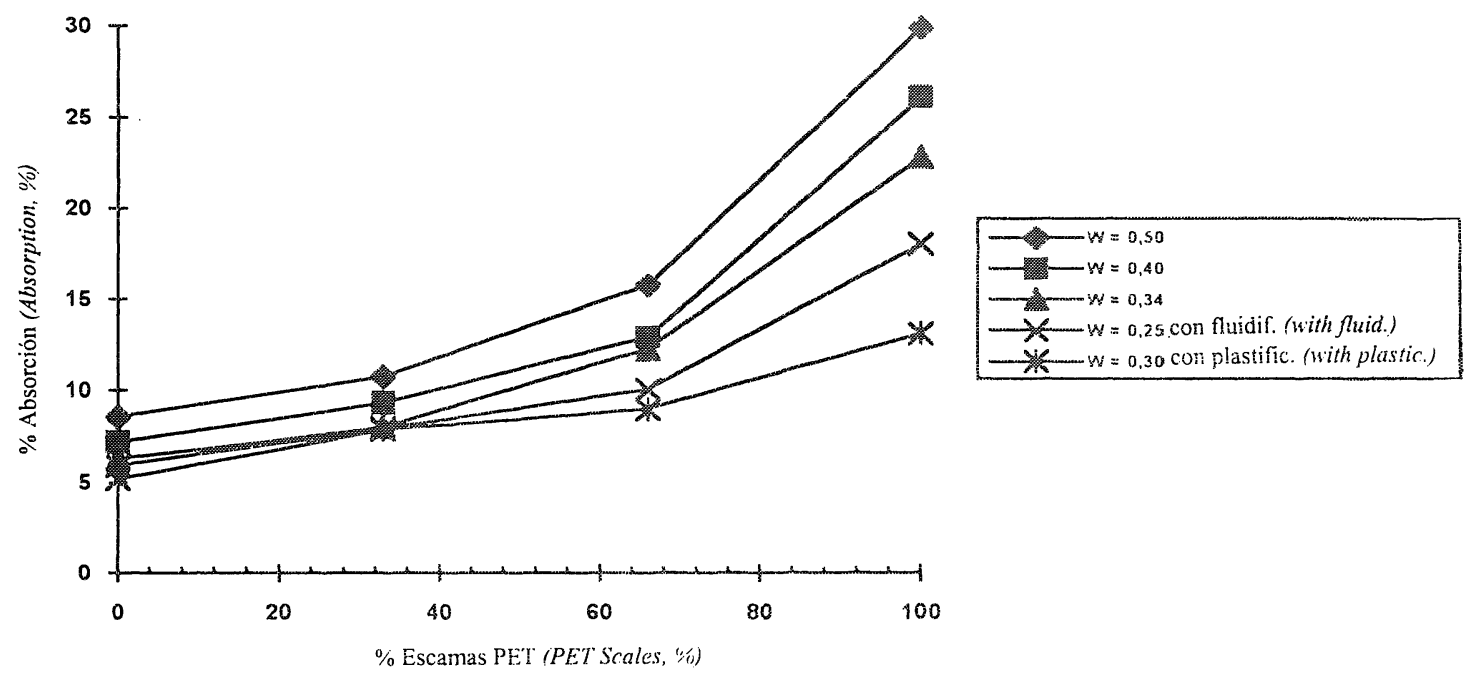

Figura I / Figure I

\section{Estado endurecido}

La rotura a flexión y compresión de las probetas se producía por la falta de adherencia en la interfase pastaagregados (escamas), lo que era previsible por la textura superficial lisa de las escamas.

Cuando el porcentaje de reemplazo llegaba al 100\%, la rotura por compresión resultó frágil, sin aviso de deformación previa. Esto se manifestó con mayor frecuencia con el uso de aditivos.

Por otra parte se comprobó que la disminución porcentual de la resistencia con respecto a la probeta patrón, es proporcional para las distintas dosificaciones (arena: PET : W).

En la figura 1 se representan valores de absorción para los distintos morteros utilizados y se observa una variación en el rango del 10 al 30\%, de acuerdo al porcentaje de escamas incorporado y a la relación aguacemento (W). Los valores son aceptables si tenemos en cuenta que el porcentaje de absorción para ladrillos cerámicos comunes varía entre un 18 y un $30 \%$ (IRAM 12549) y para bloques de hormigón es del 11 al 18\% (1561), lo que en nuestros ensayos se logra con el mortero con $66 \%$ de PET. Se observa que para las series 2 y 3 sin aditivos y con $\mathrm{W}=0,40$ y $W=0,34$ respectivamente, los valores de absorción son aproximadamente iguales, resultando ser los morteros con $\mathrm{W}=0,40$ más apropiados, teniendo en cuenta su docilidad y homogeneidad.

En la figura 2 se observa que a medida que se reemplaza el árido natural por escamas, el peso unitario o peso

\section{Mardened sate}

Cracking by flexion and compression of test cylinders were related with a low adherence of the interface scales-paste because of the smooth texture of the PET scale surface.

When percentage of replacement was $100 \%$, cracking by compression was improved and the mortar cracked without any previous deformation. This was incremented by the use of additives.

In another hand is was proved that the percentage decrease of resistance according to the control sample is proportional for the different dosages (sand: PET: W).

In figure 1, it was observed that absorption varied between 10 and $30 \%$ according to the percentage of added scales and to $W$. The results obtained with $66 \%$ replacement of sand by PET were in agreement with that corresponding to ceramic bricks (18 to $30 \%$ ) (IRAM 12549) and to concret blocks (11 to 18\%) (IRAM 1561). In the series 2 and 3 without additives, $W=0.40$ and $W=0.34$ respectively, absorption values were similar. The mortars with a $W=0.40$ were more homogeneous and presented a better ductility.

In figure 2, when sand was replaced by PET scales, the mortar unit weight decreased. A 100\% value was given 


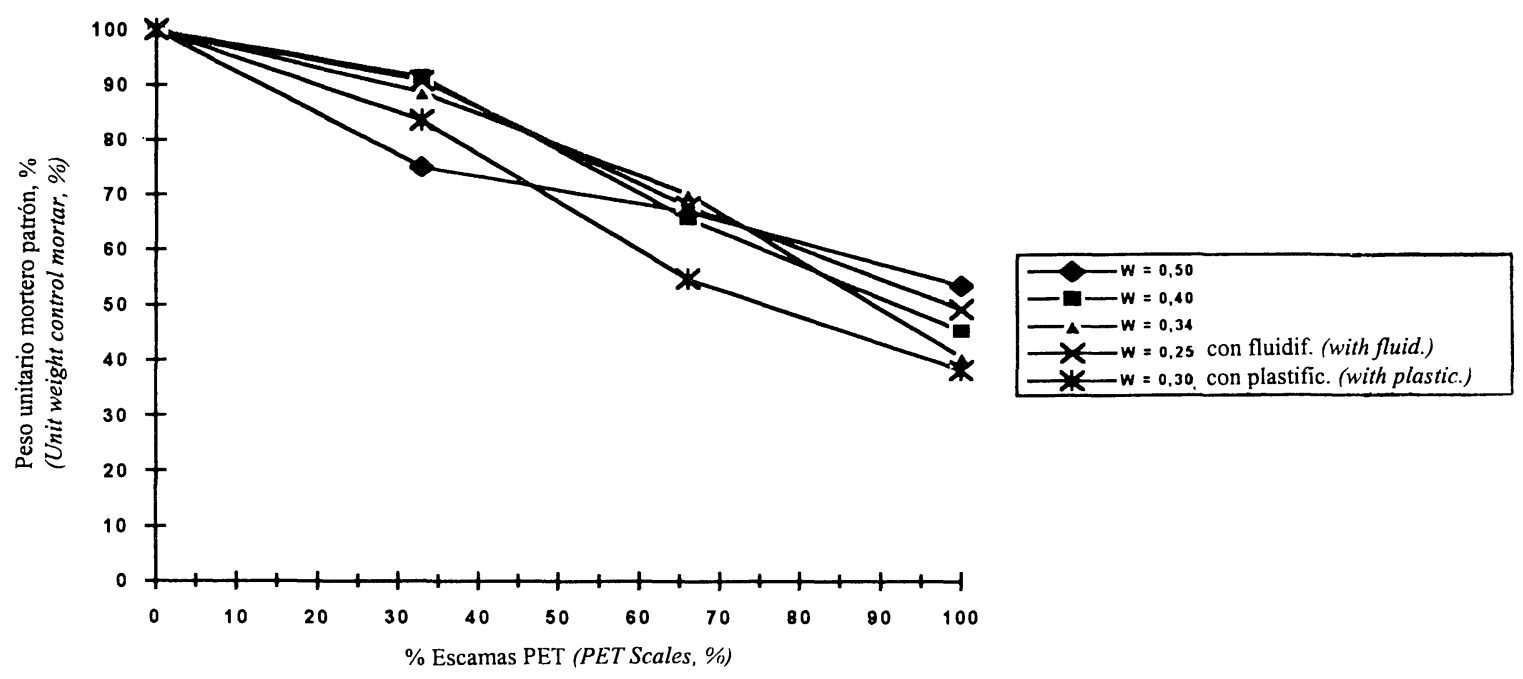

Figura 2 / Figure 2

específico aparente del mortero disminuye en todos los casos estudiados. E1 100\% corresponde a cada mortero patrón sin agregado de escamas PET y con una proporción cemento:áridos de 1:3.

Uno de los valores más representativos fue el de $1.000 \mathrm{~kg} / \mathrm{m}^{3}$, obtenido con el mortero sin aditivos especiales con $\mathrm{W}=0,40$ y $100 \%$ de reemplazo de arena por PET. Si bien para morteros con $\mathrm{W}=0,50$ con un $33 \%$ de escamas se obtiene un porcentaje mayor de reducción del peso unitario del mortero patrón, que los correspondientes a las otras series sin aditivos y con igual contenido de escamas, al incrementar el porcentaje de reemplazo al $66 \%$, las series $2(\mathrm{~W}=0,40)$ y $3(\mathrm{~W}=0,34)$ se comportan iguales, con un valor promedio de peso unitario de $1.500 \mathrm{~kg} / \mathrm{m}^{3}$, valor que corresponde aproximadamente a un $65 \%$ del valor absoluto del mortero patrón de cada serie.

En la figura 3 se observa que con la serie $2(\mathrm{~W}=0,40)$ se obtienen mejores valores de resistencia a la compresión a los 28 días, en especial con el $33 \%$ de escamas, cuyo valor es igual al de la probeta patrón sin agregado de aditivos ni de escamas PET y con una proporción de cemento: áridos de 1:3. La resistencia a la compresión a los 28 días desciende a un $50 \%$ del valor de referencia cuando la mezcla se realiza con el $66 \%$ de reemplazo de escamas.

En las figuras 2 y 3, se analizan las variaciones del peso unitario y de la resistencia a la compresión a 28 días respectivamente, en función del porcentaje de escamas PET incorporado a las mezclas. En ambos casos, se grafican todos los valores de las distintas series como to each control mortar without addition of PET scales and with a 1:3 ratio of cement/arid.

Mortars with $100 \%$ sand replacement by PET without any additive and $W=0.40$ had a unit weight of $1.000 \mathrm{~kg} / \mathrm{m}^{3}$. Mortars with $W=0.50$ and $33 \%$ of replacement by scales showed a larger unit weight reduction respect of the control mortar, when compared with mortars without additives and the same scales content. When the percentage of replacement was $66 \%$, series $2(W=0.40)$ and series $3(W=0.34)$ a similar behavior was observed with an average unit weight of $1.500 \mathrm{~kg} / \mathrm{m}^{3}$. This value was nearly the $65 \%$ of absolute value of the control mortar of each series.

In figure 3, mortars of the series $2(W=0.40)$ reached the best resistances to compression at 28 days. Mortar with $33 \%$ of replacement of arid by scales presented the same value as the control mortar with no additives and no PET and a 1:3 cement/arid ratio. Resistance to compression at 28 days decreased $50 \%$ of the reference value when $66 \%$ of sand was replaced by scales.

Figures 2 and 3 show the variation in the unit weights and in resistance to compression at 28 days as a function of percentages of PET scales added to mixtures. In both cases, values were expressed as percentages of the absolute control mortar ( mortar 


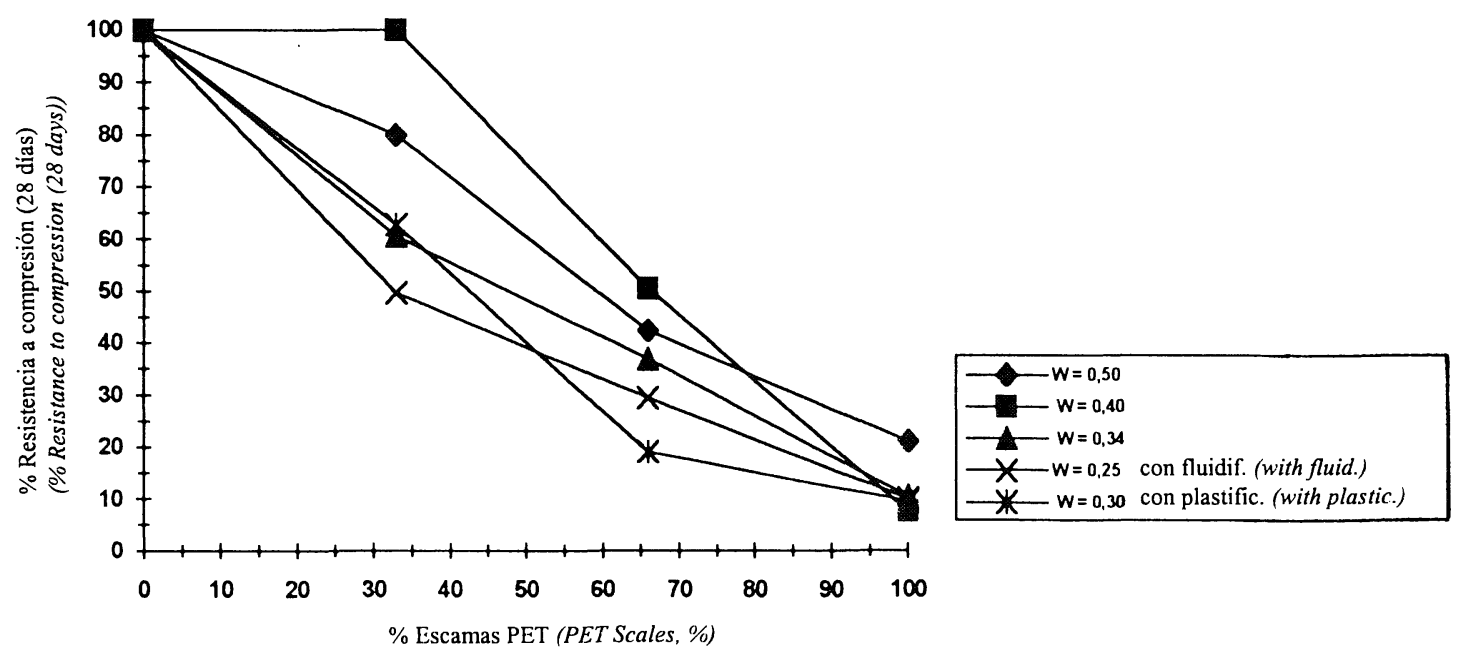

Figura 3 / Figure 3

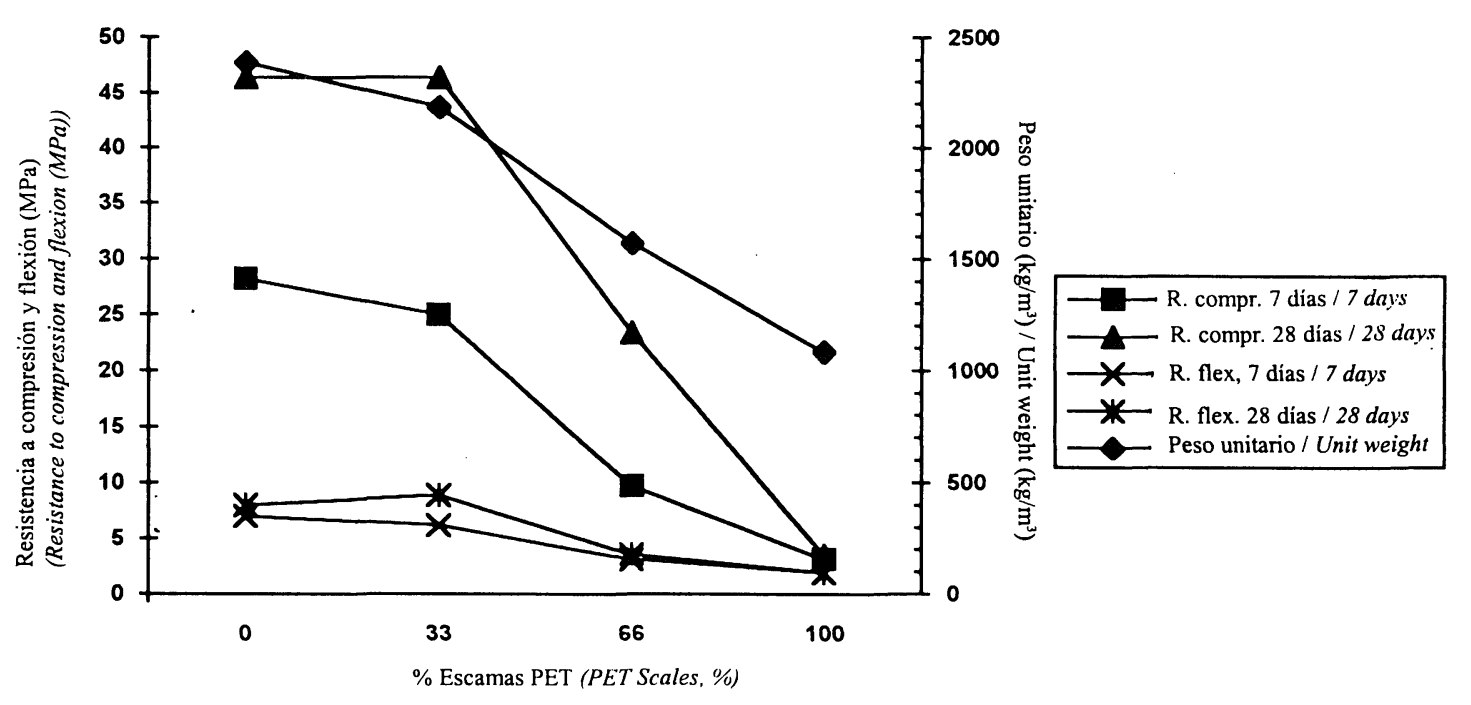

Figura 4 / Figure 4

porcentajes del valor absoluto del patrón,

correspondiente al mortero sin escamas de cada una de las series. Debe tenerse en cuenta que además del agregado de escamas, los valores obtenidos dependen de la relación agua-cemento de cada serie.

En la figura 4 se observa que los morteros correspondientes a la serie 2 con $\mathrm{W}=0,40$, superan el valor mínimo de resistencia a la compresión exigido por la Norma IRAM 11561, para bloques portantes, correspondiente a 5,2 $\mathrm{MPa}$, cuando los porcentajes de reemplazo de árido por escamas PET son del 33 y del $66 \%$, y disminuye el peso unitario de los mismos con respecto al mortero patrón $\left(2.386 \mathrm{~kg} / \mathrm{m}^{3}\right)$ a medida que aumenta el agregado de escamas. without scales) value of each series. Results obtained were affected not only by the presence of PET scales but for the $W$ of each series.

In figure 4, it was observed that mortars of the series 2 with $W=0.40$, showed resistance to compression values higher than the corresponding value indicated by the IRAM 11561 norm in the case of brickwork blocks ( 5.2 $M P a)$ when percentages of replacements of sand by scales were $33 \%$ and $66 \%$. Unit weight of mortars were lower than the control one $\left(2.386 \mathrm{~kg} / \mathrm{m}^{3}\right)$ and this difference was increased as addition of scales increased. 
La disminución de $\mathrm{W}$, lo que normalmente se logra adicionando plastificantes o fluidificantes que no son necesarios cuando incorporamos escamas, permite lograr mayor trabajabilidad de la mezcla fresca, mayor cohesión, disminuyendo, por lo tanto, el peligro de segregación de los componentes, menor exudación y mayor impermeabilidad.

\section{Ensayos de durabilidad}

Los resultados obtenidos se presentan en la figura 5.

Entre el primer y el segundo día se produce una retracción en la longitud de las barras, comparada con la barra patrón de medición, como consecuencia del fraguado, permaneciendo a $20^{\circ} \mathrm{C}$ en agua fría y luego en agua caliente a $80^{\circ} \mathrm{C}$, manteniéndose los valores medidos más altos en la barra de mortero patrón que en la del mortero PET. Luego de permanecer las probetas 9 días en la solución de $1 \mathrm{~N} \mathrm{NaOH} \mathrm{a} 80^{\circ} \mathrm{C}$ se observa expansión en ambas de $+0,059$ para el mortero patrón y de $+0,049$ para el mortero PET; valores que se mantienen constantes entre el tercero y décimosexto día (13 días de comenzar el ensayo en $1 \mathrm{~N} \mathrm{NaOH}$ a $80^{\circ} \mathrm{C}$ ) (Tabla 9). Si tomamos la diferencia
Decrease of $W$, which was usually obtained adding plasticizer or fluidizer, was performed by the addition of scales, results showed that mortars had an improved workability in the fresh state and higher cohesivity, therefore segregation of mortar components was significantly decreased with lower exudation and higher impermeability.

\section{Durability assays}

The results obtained shee in figure 5.

Retraction of bars between the first and second days, was larger in control mortar than in PET mortar. After 9 days of incubation in $1 \mathrm{~N} \mathrm{NaOH}$ at $80^{\circ} \mathrm{C}$, the expansion in both mortars (+ 0.059 for control mortar and +0.049 for PET-mortar) was observed. These values remained nearly constant from day 3 to day 16 (Table 9). Difference in measurement between day 2

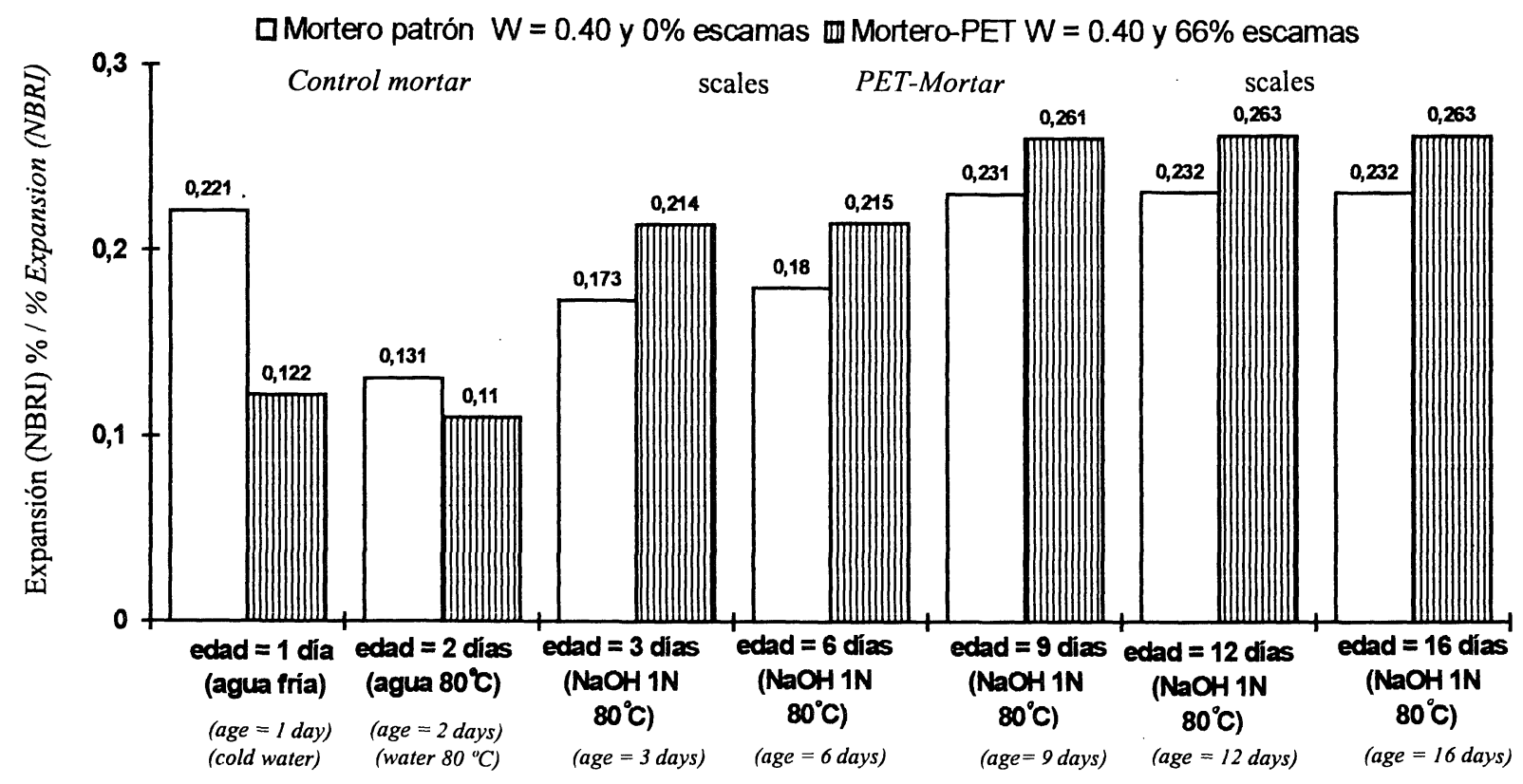

Figura 5 / Figure 5

TABLA 9 (TABLE 9)

\begin{tabular}{|c|c|c|c|}
\hline \multicolumn{4}{|c|}{ Límites de expansión críticos (Critical expansion (imits) } \\
\hline $\begin{array}{l}\text { Patrocinantes del método } \\
\text { (Method authors) }\end{array}$ & $\begin{array}{c}\text { Mayoría de los autores } \\
\text { (References } 5,6)\end{array}$ & $\begin{array}{c}\text { Otos } \\
\text { (References 7,8) }\end{array}$ & $\begin{array}{l}\text { Ensayos con mortero PET } \\
\text { (PET mortar (this work)) }\end{array}$ \\
\hline $\begin{array}{l}0,110 \% \text { a las } 12 \text { días* } \\
(0.110 \% \text { at } 12 \text { days*) }\end{array}$ & $\begin{array}{l}0,100 \% \text { a los } 14 \text { días* } \\
\left(0.100 \% \text { at } 14 \text { days }{ }^{*}\right.\end{array}$ & $\begin{array}{l}0,150 \text { a los } 14 \text { dias* } \\
\text { (0.150 at } 14 \text { days*) }\end{array}$ & $\begin{array}{l}0,049 \text { a los } 13 \text { días* } \\
\left(0.049 \text { at } 13 \text { days }{ }^{*}\right)\end{array}$ \\
\hline
\end{tabular}

* Diferencias porcentuales en solución alcalina 1 " Percentages differences in alkaline solution) 
entre el segundo día del ensayo (agua caliente a $80^{\circ} \mathrm{C}$ ) y el décimosexto día, la diferencia en el patrón es de $+0,101$; en PET es $+0,151$.

Según la bibliografía (4), los resultados demuestran que los valores de expansión del mortero por reacción álcalis - sílice, si bien pueden estar influenciados por el contenido de álcalis y la expansión en autoclave del cemento, existen otros factores que modifican los valores finales del ensayo (composición porcentual, finura, etc.). Algunos autores recomiendan la necesidad de establecer criterios de aceptación regionales, basados en la petrografía de los áridos.

La brecha existente entre 0,100 y 0,250 no se encuentra totalmente resuelta, coexistiendo dentro de ella agregados deletéreos de reacción lenta o diferida y agregados de características inocuas, pero petrográficamente marginales. La norma ASTM C 1260 adopta el criterio de considerar dicha brecha delimitada entre 0,100 y $0,200 \%$ de expansión, recomendando, en caso de que los resultados obtenidos caigan dentro de esta zona, ensayos adicionales para mayor seguridad. Algunos autores recomiendan emplear como valor de expansión crítico el $0,330 \%$ a los 28 días (4).

\section{Microscopía electrónica de las interfases de los morteros}

Se seleccionaron dos muestras para estudio de la interfase por SEM : mortero control (cemento-arena) (Fotografias 2, 2, 2) y mortero- PET (cemento - arena - 66\% de escamas de PET agregadas) (Fotografías 1 , $\left.1_{b}, 1_{c}\right)$. En ambos casos la W fue de 0,40 y las muestras se analizaron a los seis meses de edad.

La microestructura de la pasta cemento arena del mortero control permitió observar la formación de silicatos de calcio hidratados (CSH) con la característica forma de agujas elongadas y entrecruzadas y una homogénea distribución de los componentes, usual en este tipo de mezclas.

La microestructura de la interfase del mortero - PET mostró menor adherencia de los componentes probablemente debido a las propiedades físicas de las escamas plásticas que poseen una superficie lisa y plana y sin absorción. Se observaron partículas aisladas, posiblemente de cemento no integrado a la pasta.

\section{CONCLUSIONES}

\section{De orden técnico}

Seleccionamos el mortero tipo 2, con $\mathrm{W}=0,40$ (Figura 4) con reemplazo de escamas de PET del $66 \%$, como el más apropiado por las siguientes razones : (warm water $80^{\circ} \mathrm{C}$ ) and day 16, were for control mortar, +0.101 and for PET-mortar, + 0.151.

These results demonstrated that expansion of mortar by alkali reaction was dependent not only of the alkali content but of composition and finesse of mixtures (4).

The difference range between 0.100 and 0.250 is not clear, allowing deleterious aggregates of slow reaction, not dangerous but marginal when petrography is considering. ASTM C 1260 norm allow expansion values in the range of 0.100 and $0.200 \%$ and suggest that additional assays must be performed for better assurance. Some authors recommended $0.330 \%$ as critical expansion value at the age 28 days (4).

\section{Scanning electron microcopy (SEM) of interfaces of mortars}

Two samples were seected for SEM interface analysis: control mortar with cement and sand (Photos $2_{a}, 2_{b}, 2_{c}$ ) and PET mortar with cement, sand and $66 \%$ of added PET scales (Photos $1_{a}, 1_{b}, 1_{c}$ ). In both cases, $W$ was 0.40 and mortars were studied at the age of six months.

Microstructure of cement-sand paste of control mortar allowed to observe the usual development of calcium silicates hydrates (CSH) and typical shape of elongated and cross-beeded spires. Homogeneuos distribution of components of the mixture was also usual in pastes with a good absoption.

Microstructure of cement-sand-PET scales showed less adherence of the components and this was probably due to physical properties of the plastic scales wich presented a smooth and plane surface and no absorption at all. Some little portions of cement were not perfectly incorporated in the paste.

\section{CONCLUSIONS}

\section{Technical order}

The mortar of the series 2, with $W=0.40$ (Figure 4) with $66 \%$ of replacement of sand by PET scales, was preferred for the following reasons: 


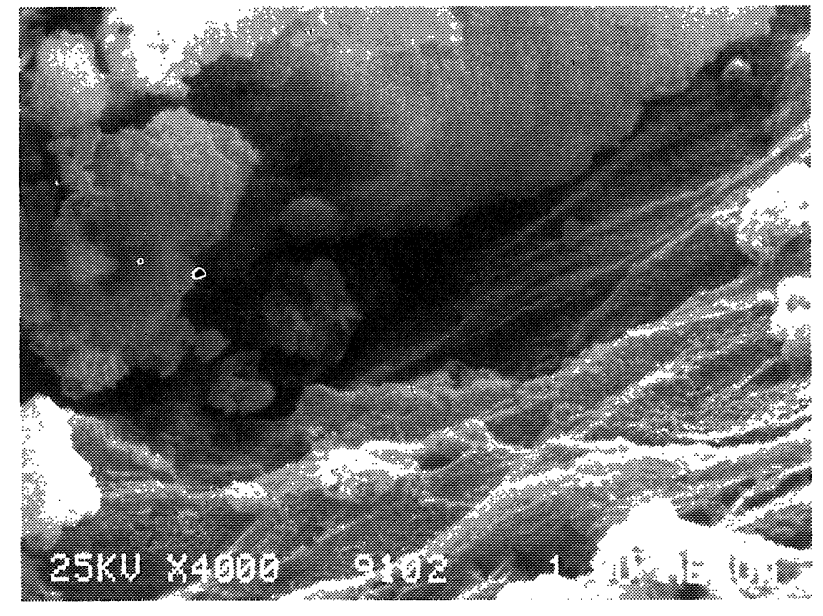

a)

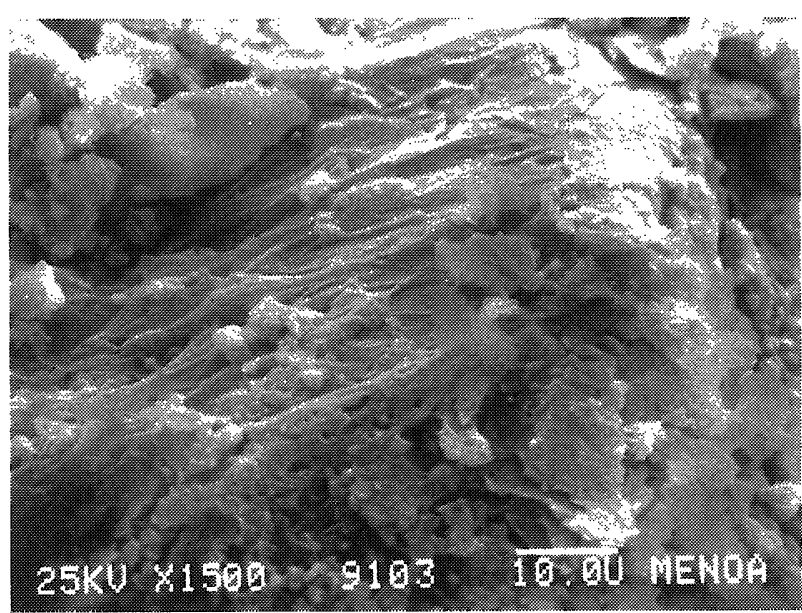

b)

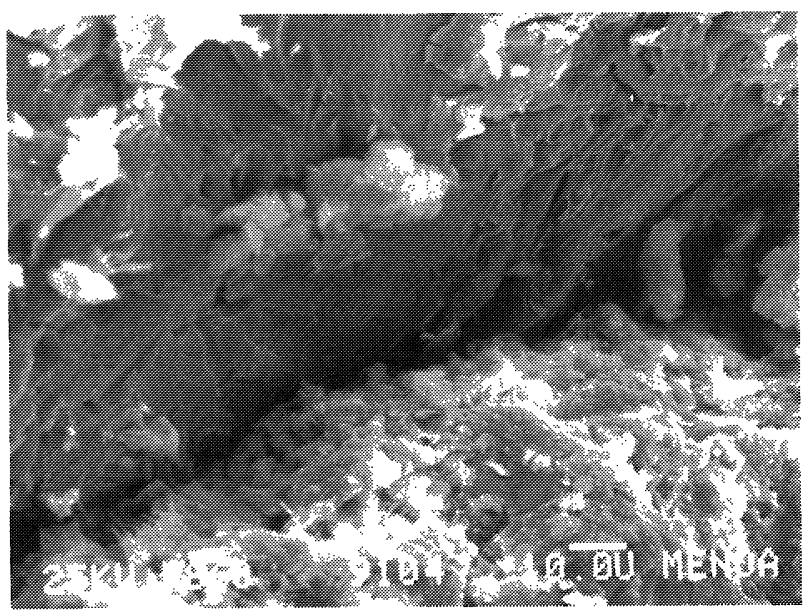

c)

Foto 1.- Microfotografia clectrónica de probeta con PLT.

Photo 1.- Scanning electron microscopy of the experimental test cylinder.

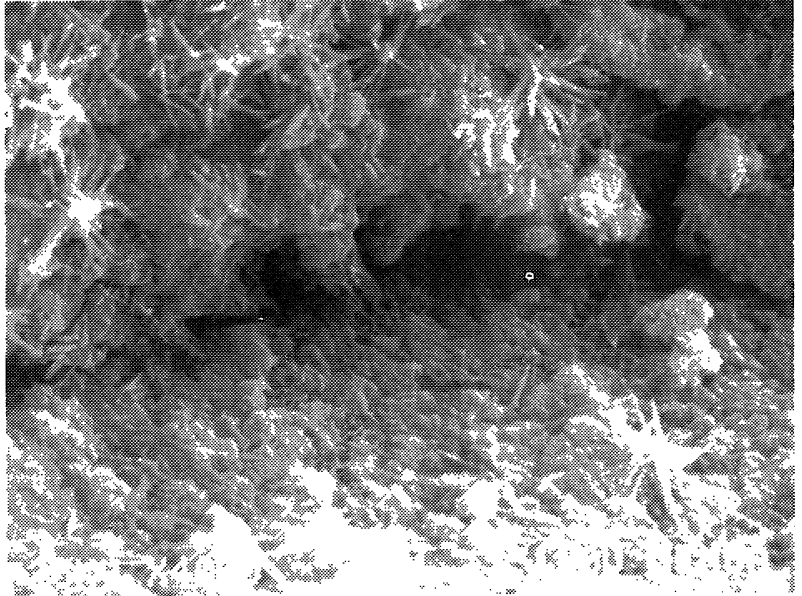

a)

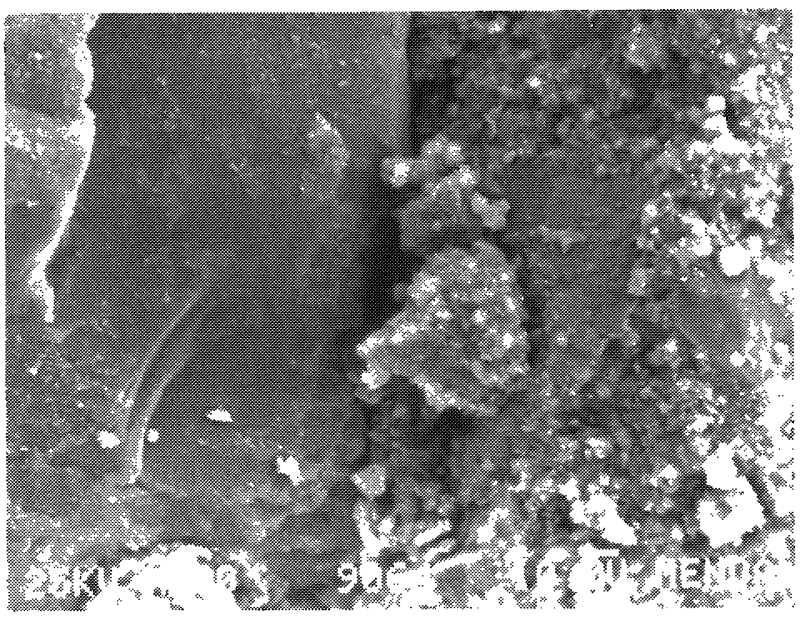

b)

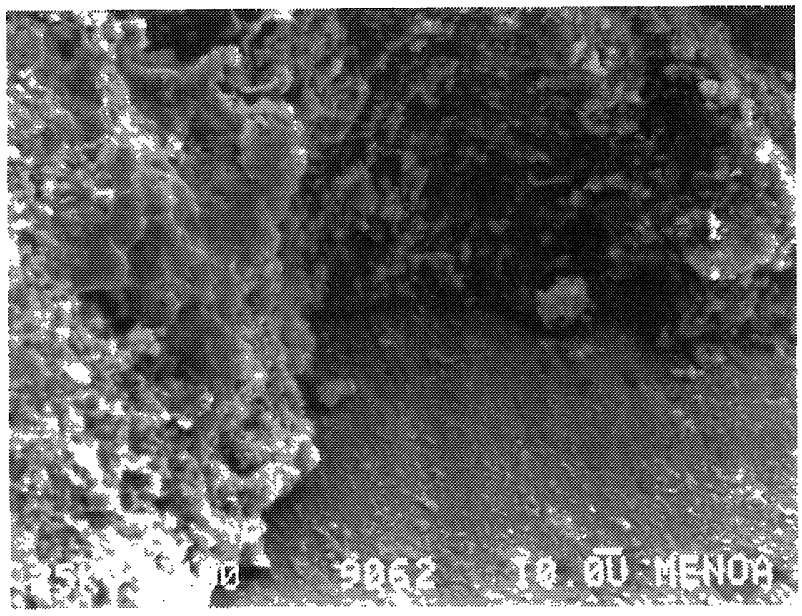

c)

Foto 2.- Microfotografía electrónica de probeta patrón.

Photo 2.- Scanning electron microscopy of the control test cylinder 
- Posee una fluidez óptima para lograr la trabajabilidad necesaria para la fabricación de bloques de hormigón, motivo del presente estudio. No es necesario incorporar aditivos, que significan costos adicionales, sin ventajas apreciables.

- Responde a las exigencias de las normas IRAM 11561 para bloques, con respecto al porcentaje de absorción, pudiendo ser menores en caso de mejorar la granulometría del PET.

- Cumple, con los valores exigidos por la norma IRAM 11561, con respecto a resistencia a rotura por compresión para bloques portantes.

- Logramos facilitar la mano de obra al reducir el $35 \%$ del peso unitario del mortero patrón, reemplazando el $66 \%$ del peso de la arena por escamas de PET sin necesidad de aditivos.

- Presenta diferencias mínimas respecto al uso de aditivo plastificantes, que influirían aumentando el costo final del producto, razón por lo cual se descartan los ensayos con $\mathrm{W}=0,25$ y 0,30

- En el transporte, el menor peso del PET, comparado con el del arena, da lugar a un volumen más reducido de gases de combustión (monóxido de carbono) a la atmósfera, con la consiguiente menor contaminación de ésta.

-En el estudio de reactividad alcalina potencial los valores son aceptables, pero merecen un mayor estudio dada la falta de antecedentes y parámetros regionales para establecer estándar.

- En estudios posteriores se buscará una curva granulométrica más extendida de las escamas de PET, para incidir directamente en la trabajabilidad y la docilidad de la mezcla, entre otras propiedades.

\section{De orden económico}

- El ahorro de materia prima prolonga la explotación de las canteras naturales.

- La fabricación de PET demanda un consumo energético que puede ser recuperado reutilizando dicho material en lugar de descartarlo en vaciaderos municipales en donde genera problemas ambientales.

- El menor peso del PET permite ahorro de combustible. También influye directamente en la reducción del tonelaje de los componentes constructivos y, por ende, menor sección de los elementos estructurales que sostengan los mampuestos realizadas con mortero-PET.
- It had an optimal fluidity which allowed a very good workability for concrete block making. It was not necessary to add any additives, reducing additional costs.

- It was in agreement with international specifications (IRAM 11561) for blocks regarding percentage of absorption. The value obtained in this work would probably be improved if granulometric properties of PET scales were also improved.

- Resistance to cracking by compression was in accordance to IRAM 11561 norm.

- Making mortar became easier because of a $35 \%$ of reduction in the unit weight when $66 \%$ of the sand weight was replaced by PET scales in the mixture without additives.

- No significative differences were observed when plasticizer was added so this additive was not necessary allowing to reduce the overall cost of the process.

- Lower unit weight of bricks with PET would probably result in lower combustion (carbon monoxyde) and less air contamination.

- Alkaline potential reactivity values obtained were in agreement to mean values usually accepted but this study would be performed more extensively in the future because no regional standard parameters are actually available.

- In future studies, the granulometric curve of PET scales will be improved in order to get better workability and ductility of mixtures.

\section{Economical order}

- Less raw material requirement (sand), increases the natural quarry life.

- The energy consumed in PET fabrication can be partially reduced by recycling the material.

- Lower PET weight reduces the constructive component weight and thinner structural component section can be utilized. 
- Al ser más livianos, mejoran el proceso de operación y la productividad (horas hombre por $\mathrm{m}^{2}$ ).

- En general el precio de extracción, limpieza, triturado y transporte está suficientemente compensado por los mencionados ahorros.

\section{De orden ecológico}

- La utilización de escamas plásticas de PET, como sustituto del agregado natural, demostró ser factible según los resultados obtenidos es esta primera parte del presente estudio, brindando una alternativa de reciclaje conducente a reducir el impacto ambiental producido por los desechos industriales y urbanos.

- Existen razones ecológicas ligadas a las de carácter económico, ya que al disminuir el uso de materias primas naturales, disminuye la explotación de las canteras de áridos con menor deterioro paisajístico y ambiental. Otra razón a tener en cuenta es la restauración del terreno en las zonas de canteras en explotación o agotadas y abandonadas. El aprovechamiento del PET reduce su acumulación en los vaciaderos, por ser un material no biodegradable.

\section{AGRADECIMIENTOS}

Los autores desean expresar su agradecimiento a:

- Arq. Rafael Mellace, Director del Laboratorio de Ensayo de Materiales y Edificios (LEME) de la Fac. de Arquitectura de la U.N.T., por su valiosa colaboración al brindarnos la posibilidad de realizar los ensayos en dicho laboratorio.

- Dr. Faustino Siñeriz, Director de la Planta Piloto de Procesos Industriales Microbiológicos (PROIMI), por el uso de los laboratorios de la planta y por la exhaustiva corrección del presente manuscrito.

- Ing. Nélida Castría, Directora del Laboratorio de Materiales de la Fac. de Ciencias Exactas de la U.N.T., por su valiosa colaboración..

- Dr. Ricardo Farías, Director del Laboratorio de Microscopía Electrónica del Noroeste Argentino (LAMENOA) y al personal docente y técnico de dicho laboratorio.

- Al Sr. Luis María Carballo, Director Gerente de ENVASES PLASTICOS S.A.Y.I.C., proveedor de las escamas de PET en carácter de donación.

- Al Sr. Esteban Valoy, laboratorista del LEME por su asistencia técnica.
- Also the productivity (man hour $/ m^{2}$ ) and operation procedures are improved.

- Costs involved in recollection, washing, crushing and transportation can be optimized according to each regional recycling program.

\section{Ecological order}

- Utilization of PET scales as a partial substitute of natural arids is possible according to the results obtained in this work. PET mortars showed improved characteristics and the use of post-industrial plastics would reduce the environmental impact of urban and industrial residues.

- Ecological reasons as well as economical ones have been taken in account. Reducing natural raw material (sand) will allow a lower exploitation of arids. When less quarries are exploited, environmental and urban detriment is reduced. Reutilization of PET in the construction industry is a partial solution to its accumulation and can be taken in account as a viable recycling alternative.

\section{ACKNOWLEDGEMENTS}

The authors would like to record their thanks to:

- Arq. Rafael Mellace, Director of Laboratory of Material and Building Tests (LEME), Faculty of Arquitechture of National University of Tucumán, for his valious collaboration.

- Dr. Faustino Siñeriz, Director of Microbiological Industrial Processes Pilot Plant (PROIMI), for the use of laboratories and the correction of the manuscript.

- Ing. Nélida Castría, Director of Laboratory of Materials, Faculty of Exact Science of National University of Tucumán., for her useful comments.

- Dr. Ricardo Farias, Director of Laboratory of Electronic Microscopy (LAMENOA) and all the members of this lab for their professional assistance.

- Sr. Luis Maria Carballo, Director of Envases Plásticos S.A.Y.I.C., for providing us the PET scales.

- Sr. Esteban Valoy from LEME, for his technical assistance. 


\section{BIBLIOGRAFÍA}

(1) Proceedings of The International Brick and Block Masonery, "Brick and Block Masonry", Edited by de Courcy, John W., "Elsevier Applied Science Publisher L.T.D.” England, Vol. I, 1988, pp 33 - 40. Proceedings of The International Conference on Recent Developments in Fibre Reinforced Cements and Concretes," Fibre Reinforced Cements and Concretes Recent Developments", Edited by Swamy R.N. and Barr B., "Elsevier Applied Science Publisher L.T.D" England, 1989.

(2) MELLACE R., "Hormigones de alto desempeño con agregados naturales" la parte, LEME ISSN 0328 CAICYT/3259 CONICET, 1995.

(3) WEAST, R.C. AND ASTLE, M.J., (eds.). Properties of Commercial Plastics in: "Handbook of Chemistry and Physics". 62d edition, 1981-1982. CRC Press, Inc. Boca Ratón, Florida. page C-750. CRC.

(4) BATICO.R., MILANESI C.A., SOTA J.D., 1996 "Metodo de ensayo acelerado de la barra de mortero (NBRI). Una revisión crítica con miras a su normalización", Revista de la Asociación Argentina de Tecnología del Hormigón, N²9.

(5) FOURNIER, B. AND BÉRUBÉ, M.A., 1991 “Cement and Concretes Research” 21, pp 1069-1081.

(6) HOOTON, R.D. AND ROGERS, C.A., 1989 Procedding of 8th International Conference on AAR in Concret. pp 439-444. K.Okada et al (eds). Kyoto, Japan.

(7) Cement Aggregate Reactivity Sub-Commitee CSA-A5 Task Group. Proposed Changes to CSA A23.1 and A23.2 As Regards Alkali-Aggregate Reactivity and Associated Test method. Draft Document, 1992.

(8) KLARIC M.E.. Memorias del Seminario sobre la reacción Alcali-Sílice (RAS), 1990. LEMIT. pp 63-79. La Plata, Argentina.

\section{publicación del IETCC/CSIC}

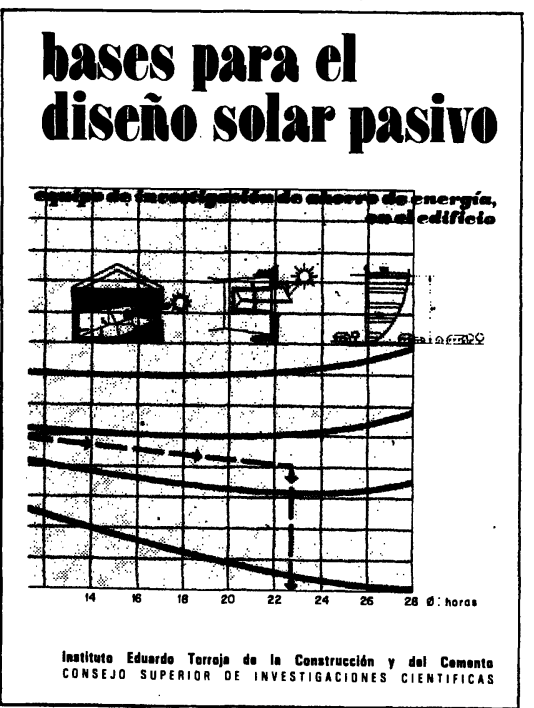

Equipo de Ahorro de Energía en el edificio

Dirección y coordinación: Arturo Garcia Arroyo

M. a José Escorihuela

José Luis Esteban

José Miguel Frutos

Manuel Olaya

Bernardo Torroja
Las dificultades de suministro y el alto coste de los productos energéticos convencionales han despertado la atención de los usuarios técnicos $e$ industriales de la edificación hacia los procedimientos y sistemas en que se basa el aprovechamiento de otras fuentes alternativas de energia, principalmente la solar. Esto ha generado un rapido desarrollo industrial ha genera un prapido desarillo industrial y este libro, arrastran los siguientes defectos: un mimético tecnologismo respecto de los sistemas convencionales que violenta las pe culiaridades de la energía solar (baja densidad y variabilidad en el tiempo), y una escasa selectividad en la aplicación de los sistemas y procedimientos pasivos dando origen a un ecumenismo arquitectónico solar, al margen de las condiciones climáticas y funcionales especificas de cada caso y lugar.

En este libro, utilizando criterios y metodología pedagógicos, se dan los fundamentos $e$ instrumentos teórico-prácticos necesarios para el planteamiento de todo proyecto arquitectónico solar pasivo, de acuerdo con los principios éticos y económicos de conservación y ahorro de energia. Es decir: respeto de los presupuestos bioclimáticos, búsqueda de la máxima captación y acumulación de la radiación solar, y esmero en el aislamiento térmico de los cerramientos.

Un volumen encuadernado en cartulina ibiza plastificada, a cinco colores, de $16 \times 23 \mathrm{~cm}$, compuesto de 216 páginas, 217 figuras, 87 gráficos, 19 tablas y 10 cuadros. 